\title{
Trace-element systematics of pyrite and its implications for refractory gold mineralisation within the carbonaceous metasedimentary units of Palaeoproterozoic South Purulia shear zone, eastern India
}

\author{
Subhashree Majumdar, Sahendra Singh* (i), Prabodha Ranjan Sahoo \\ and A S VENKATESH \\ Department of Applied Geology, Indian Institute of Technology (Indian School of Mines), Dhanbad 826 004, India. \\ *Corresponding author. e-mail: sahendrasingh02@gmail.com
}

MS received 10 January 2018; revised 10 June 2019; accepted 13 June 2019

Globally, refractory gold occurs in significant proportions in many types of gold deposits. The present work reports the occurrence of sulphide-hosted refractory gold within the carbonaceous phyllites of the South Purulia shear zone in the Singhbhum crustal province, eastern India. Detailed textural characteristics, paragenesis and trace-element concentrations of different generations of pyrites were studied to understand their evolutionary stages and the mechanism of gold incorporation in pyrites. Four types of pyrites, which are closely associated with gold mineralisation were identified in the host rock, i.e., carbonaceous phyllite. Py I is of diagenetic origin, whereas Py II, Py III and Py IV are of hydrothermal origin. Laser ablation inductively coupled plasma mass spectrometry studies confirm the presence of invisible/refractory gold concentration up to $110.55 \mathrm{ppm}$ within these pyrites. The positive correlation between $\mathrm{Au}$ and $\mathrm{As}$ in pyrite indicates the significant role of As in the incorporation of gold in pyrite. Fourier transform infrared spectroscopy confirms the presence of organic matter that provided suitable redox conditions for the precipitation of auriferous pyrites. The refractory gold mineralisation is attributed to widespread sulphidation during both sedimentation and hydrothermal ore-forming processes. Transformation of diagenetic pyrite to pyrrhotite during prograde metamorphism of carbonaceous rocks promoted the liberation of sulphur and Au from the lattice of abundant diagenetic pyrites to the hydrothermal fluid which later precipitated sulphides in the quartz \pm carbonate veins.

Keywords. South Purulia shear zone; carbonaceous phyllite; refractory gold; arsenian pyrite; LA-ICP-MS.

\section{Introduction}

Presently, one-fourth of the world's gold production is contributed by the refractory type of gold ores. The gradual depletion of free milling gold ores will eventually lead the future gold projects to rely more on refractory gold (Yang et al. 2013). A proper understanding of the formation of refractory Published online: 31 August 2019
$\mathrm{Au}$ ores and characterisation of such ores will therefore be helpful in finding new analogous deposits and deciding on the mechanism of $\mathrm{Au}$ extraction. Although the recovery of refractory gold, especially from carbonaceous host rocks is a complex process, various ore-processing techniques such as pressure oxidation, thiosulphate leaching and resin in pulp adsorption have been developed 
to overcome these difficulties (Yannopoulos 1991; Wang et al. 1994; Thomas et al. 1998; Wan 2001; Wickens et al. 2003). Moreover, the refractory gold mineralisation needs to be studied as they have a significant role in the formation of free gold, associated with primary gold deposits (Saha and Venkatesh 2002; Sung et al. 2009; Sahoo and Venkatesh 2015).

Refractory gold ores are mainly associated with pyrites and arsenopyrites. Pyrite occurs as a predominant sulphide mineral in a wide variety of gold deposits i.e., orogenic deposits (greenstone-hosted deposit, turbidite-hosted veins, BIF-hosted, carbonaceous sedimentary rock-hosted deposit), reduced and oxidised intrusion-related deposits (intrusion-hosted mesozonal and epizonal, Au-rich porphyry, high and low-sulphidation epithermal deposits), Au-rich volcanogenic massive sulphide deposits and Carlin-type deposits (Huston 2000; Jensen and Barton 2000; Groves et al. 2003; Goldfarb et al. 2004, 2005; Cline et al. 2005; Hart 2005; Seedorff et al. 2005; Simmons et al. 2005; Groves and Santosh 2015). Pyrite may contain significant concentrations of valuable metals, in particular, gold, which occurs as solid solution, nanoparticles and free gold (Fleet et al. 1993; Palenik et al. 2004; Large et al. 2011). Pyrites with elevated arsenic content have higher potential to host gold particles (Fleet and Mumin 1997; Reich et al. 2005). The studies of textural and chemical evolution of pyrites enhance our understanding of the metallogenic environments during different stages of ore formation (Abraitis et al. 2004; Large et al. 2007; Pasava et al. 2013).

Gold occurrences have been reported from the carbonaceous metasedimentary units of the ductile to brittle-ductile South Purulia shear zone (SPSZ) (Majumdar et al. 2017). These occurrences are similar, in terms of the tectonic environment, to shear zone-hosted vein deposits as well as carbonaceous sediment-hosted gold deposits such as Lega Dembi gold deposit, Southern Ethiopia, Um El Tuyor gold deposit, Egypt, Lachlan fold belt, Australia, Sukhoi log deposit, Russia and Hatu gold deposit, NW China (Bonnemaison and Marcoux 1990; Cox et al. 1991; Tadesse 2004; Large et al. 2007; Zoheir 2008; Shen et al. 2016). The present study was carried out in the NW-SE to WNW-ESE trending SPSZ, which marks the boundary between two different tectono-metamorphic ensembles, i.e., the Chotanagpur granite gneissic complex (CGGC) in the north and the North Singhbhum mobile belt (NSMB) in the south (Acharyya et al. 2006; figures 1 and 2). The major lithounits of the SPSZ are carbonaceous phyllite, felsic volcanic rocks, quartzite, chlorite schist, mica schist and amphibolite. Detailed field and petrographic studies by earlier workers suggest that the area has suffered faulting, three phases of folding and hydrothermal alterations such as sulphidation, carbonatisation, biotitisation, silicification, ferrugination and kaolinisation (Vapnik et al. 2007; Majumdar et al. 2017). The SPSZ witnessed ductile to brittleductile shearing as evident from the presence of mylonitic foliation and hydrothermal veins (Bhattacharya 1989; Acharyya et al. 2006) that are some of the prerequisites for the hydrothermal fluid migration and mineral deposition. The SPSZ hosts the mineralisation of several metals, for example, $\mathrm{Cu}, \mathrm{U}, \mathrm{Pb}, \mathrm{W}, \mathrm{Ag}$ and $\mathrm{Au}$ and is being studied extensively for its metallogenic potential (Katti et al. 2010). Exploratory studies have been carried out in the area by the Atomic Mineral Division (Department of Atomic Energy) and the Geological Survey of India (Katti et al. 2010).

Detail mineralographic studies of borehole samples suggest that gold-sulphide mineralisation is mainly confined to the carbonaceous phyllite. Sulphides such as pyrite, pyrrhotite, chalcopyrite, sphalerite, arsenopyrite and galena are present within the quartz \pm carbonate veins. Quartz \pm carbonate veins within the host rocks are confined to variably oriented brittle-ductile shear segments, which according to Hodgson (1989) mainly form at supra-lithostatic fluid pressure during regional deformation stages. Sulphides also occur in disseminated form within the laminated/stratified carbonaceous layers of carbonaceous phyllite. This work presents detailed mineralographic evidence and mineral chemistry of pyrites to decipher mineral paragenesis and to understand the causes of trace elemental variations in different generations of auriferous pyrites associated with carbonaceous phyllites along the SPSZ. An attempt has been made to illustrate various ore-forming events and the role of organic matter in the formation of refractory gold deposit. The study of chemical and textural evolution of sulphides, mostly pyrite, is necessary for deducing the source of trace elements including precious metals such as gold in the oreforming fluids and understanding fluid-rock interaction. No analogous research work as mentioned above has been carried out earlier in the area and hence the outcome of this paper may help in unearthing similar sulphide mineralisation associated with refractory gold occurrences in the region. 


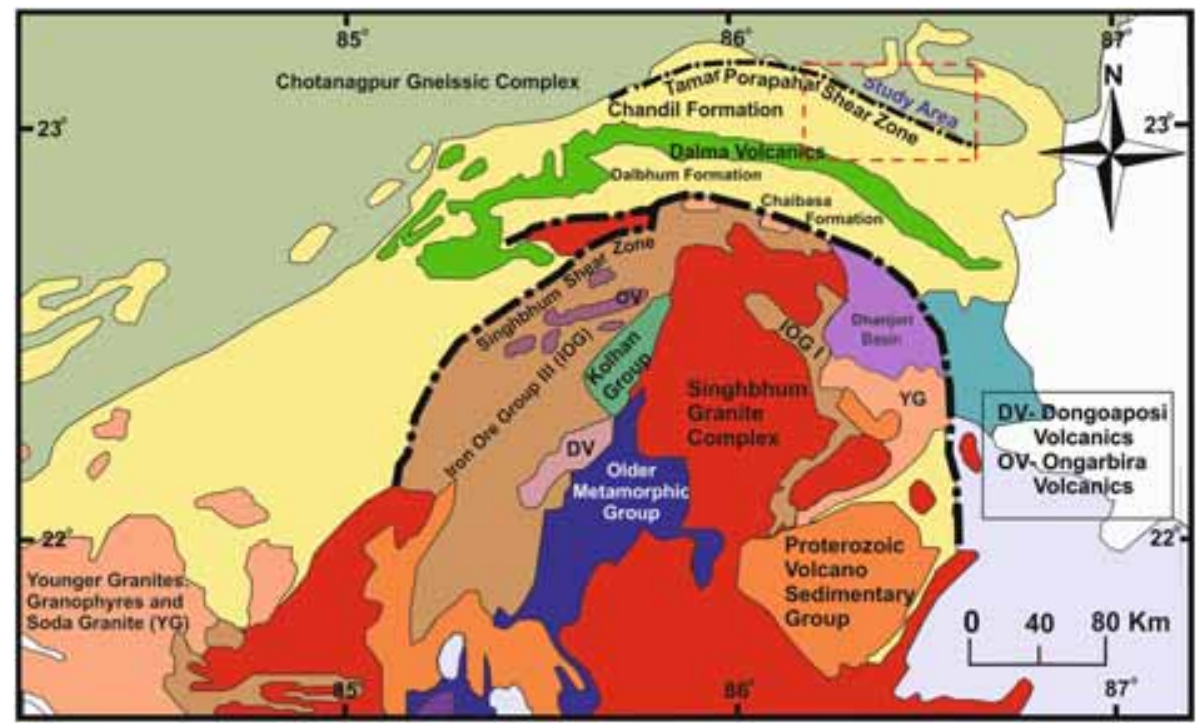

Figure 1. Regional geological map of the Singhbhum Crustal Province, eastern India showing the geological setting of the NSMB and the study area (after Sarkar et al. 1992).

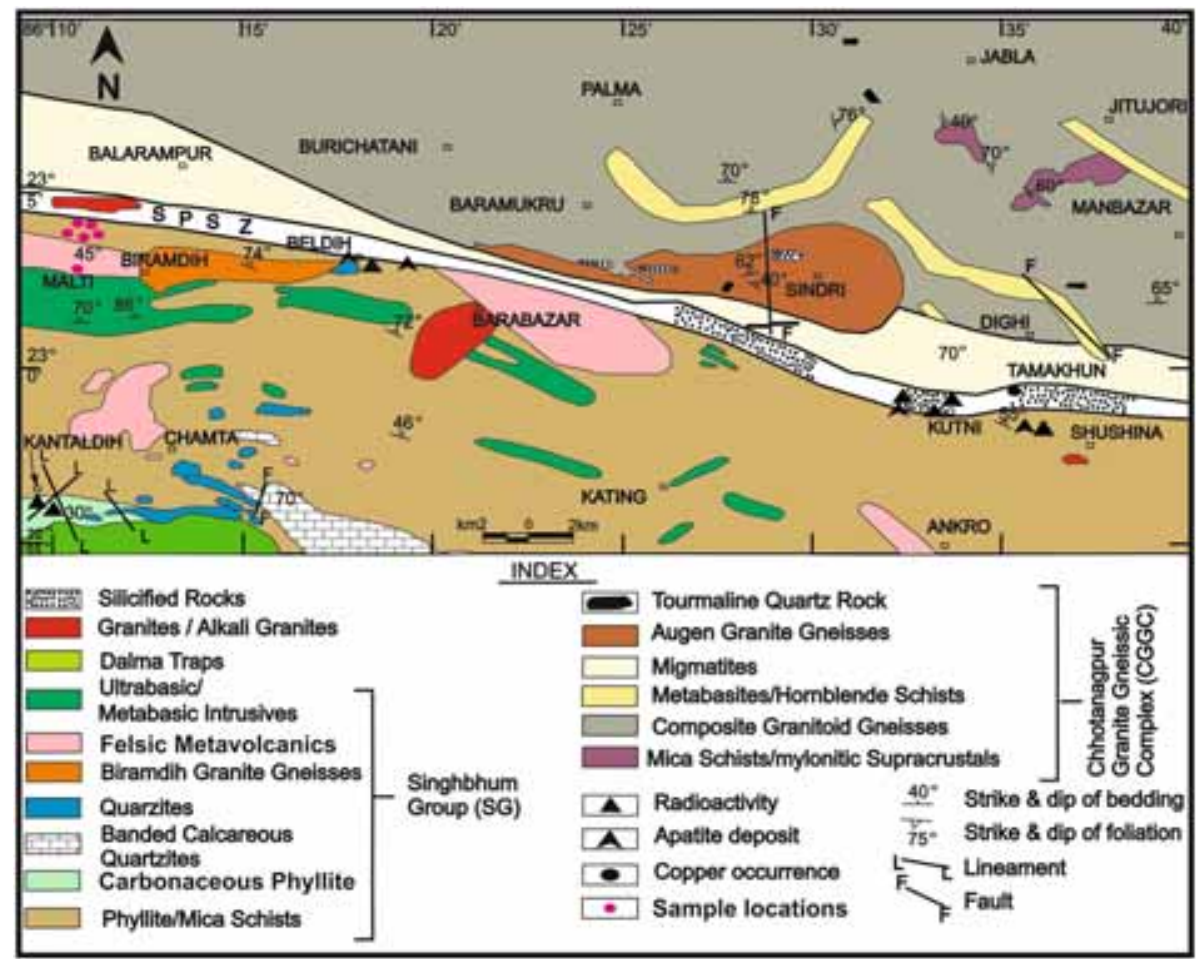

Figure 2. Geological map of the SPSZ with sample locations (after Dwivedi et al. 2011).

\section{Geological overview}

The Singhbhum crustal province covers an area of $50,000 \mathrm{~km}^{2}$ in the eastern part of India (figure 1). The Mesoarchaean Singhbhum granite complex (SGC) with an area of $8000 \mathrm{~km}^{2}$ belongs to the southern part of this province (Mishra et al. 1999). The SGC is fringed by the Meso to Neoarchaean
Iron Ore Group, which comprises low-grade metasedimentary rocks such as phyllites, tuffaceous shales, banded hematite jasper with iron ores, ferruginous quartzite, dolomite and volcanic rocks (Saha 1994). The Kolhan group comprising sedimentary units overlies the Singhbhum granite. The northern younger part of the Singhbhum crustal province is the NSMB, which is a $200 \mathrm{~km}$ 
long linear thrust belt, lying between the SPSZ in the north to the Singhbhum shear zone (SSZ) in the south (figure 1). The NSMB consists of proterozoic volcano-sedimentary succession of Dhanjori, Chaibasa, Dhalbhum, Dalma and Chandil formation (Gupta and Basu 2000). The Dalma formation comprises widely distributed mafic to ultramafic volcanic rocks (Chatterjee et al. 2013). The SSZ is $\sim 200 \mathrm{~km}$ long and lies between the NSMB and the Archaean nucleus of the Singhbhum crustal province (Pal et al. 2009). The metasedimentary rocks of the SSZ that host mostly uranium and copper deposits are highly deformed. The NSMB in eastern India is considered as a veritable province for gold occurrences with already identified prospects at Babaikundi, Birgaon, Rudia, Taramba, Lawa-Mayasera, Sindauri and Parasi (Chandan et al. 2013; Jha et al. 2015).

The ductile to brittle-ductile SPSZ stretches for a total length of about $150 \mathrm{~km}$ from Tamar, Jharkhand in the west to Porapahar, West-Bengal in the east (Acharyya et al. 2006). The $4-5 \mathrm{~km}$ wide SPSZ lies between the CGGC in the north and the NSMB in the south (figure 2). The predominant litho types are felsic volcanic rocks, amphibolite and metasedimentary rocks such as micaceous quartzite, carbonaceous phyllite, chlorite schist and mica schist with pods of carbonatite and alkaline ultramafites (Chakrabarty et al. 2009). Rocks of this shear zone have been subjected to three phases of deformation and up to greenschist to lower amphibolite metamorphism (Vapnik et al. 2007). The majority of carbonaceous phyllites have been delineated in the core samples collected from the Malti area which lies at the southern fringe of the SPSZ in the south-western part of Purulia district, West Bengal, India (figure 2). The area covered by phyllites as shown in the map is intercalated with carbonaceous phyllite. Surface exposures of carbonaceous phyllites in the Malti area are very narrow and are not on a mappable scale. These are one of the least-studied rock types, both in terms of the petrographic characteristics and mineralisation potential. Intrusive granitoids in and around Biramdih and Barabazar cover an area of $10-30 \mathrm{~km}^{2}$ and lie near the SPSZ. Previous workers have suggested that the shear zone was a narrow basin initiated by rifting in an intra-cratonic setting, with the emplacement of felsic volcanic rocks and granites followed by the generation of numerous fractures and discharge of mafic/ultramafic rocks, alkali feldspar granites and carbonatites (Sarkar et al. 1992; Gupta and Basu 2000; Acharyya et al.
2006). Subsequently sedimentary rocks were formed and covered the volcanic rocks, granites and were later metamorphosed to quartzite, phyllite and muscovite quartz schist. The shear zone started developing at the time of the closing of the rift basin, when the northern block (CGGC) was upthrusted over the southern block (the Singhbhum group). This is evident from the presence of shear indicators in ignimbrite, quartzite and mylonite (Acharyya et al. 2006). The earliest deformation produced folds (rootless or steeply inclined to reclined at some places), which are very rare and occur at some places on the bedding with an axial planar schistosity dipping north. During the compressional activities, shearing took place syn to post kinematic to $F_{1}$ folding with the generation of mylonitic foliation (Acharyya et al. 2006). The development of regional antiform and synform having the $\mathrm{E}-\mathrm{W}$ axial plane during the $\mathrm{F}_{2}$ folding led to the subsequent folding of mylonitic fabric and crenulation of $\mathrm{S}_{1}$ foliations in migmatised mica schist (Acharyya et al. 2006). $\mathrm{F}_{3}$-folds mark the latest folding which is gently plunging towards the north in an upright warp nature. Quartz reef, ferruginous breccia and quartz breccia fill the narrow crustal gaps. The $\mathrm{Pb}-\mathrm{Pb}$ dating of the Barabazar granite indicated that it was emplaced into the Singhbhum group of metapelitic and felsic volcanic rocks at $\sim 1771 \mathrm{Ma}$ during the within-plate, intracontinental rifting (Dwivedi et al. 2011). The much younger age of $\sim 1500 \mathrm{Ma}$ of the felsic volcanic rocks as revealed by the Rb-Sr isotopic studies (Sarkar and Ghosh Roy 1999; Sengupta et al. 2000) could be due to deformation and metamorphism. An age of $\sim 971 \mathrm{Ma}$ was obtained by the $\mathrm{Rb}-\mathrm{Sr}$ isotopic study of the Barabazar granite that occurs in the SPSZ and is considered to be the age of reactivation that took place during the collision of the Singhbhum group of rocks with the CGGC along SPSZ (Dwivedi et al. 2011).

\section{Petrography}

Detailed petrographic studies of the carbonaceous phyllites show the presence of sulphide mineralisation along the laminae of carbonaceous matter as well as within the quartz \pm carbonate veins (figure $3 \mathrm{a}$ and b). Sulphides such as pyrrhotite, chalcopyrite, galena and pentlandite are present as disseminated grains within the quartzite and amphibolites. The auriferous quartz \pm carbonate veins are present along and across the $S_{1}$ foliation 

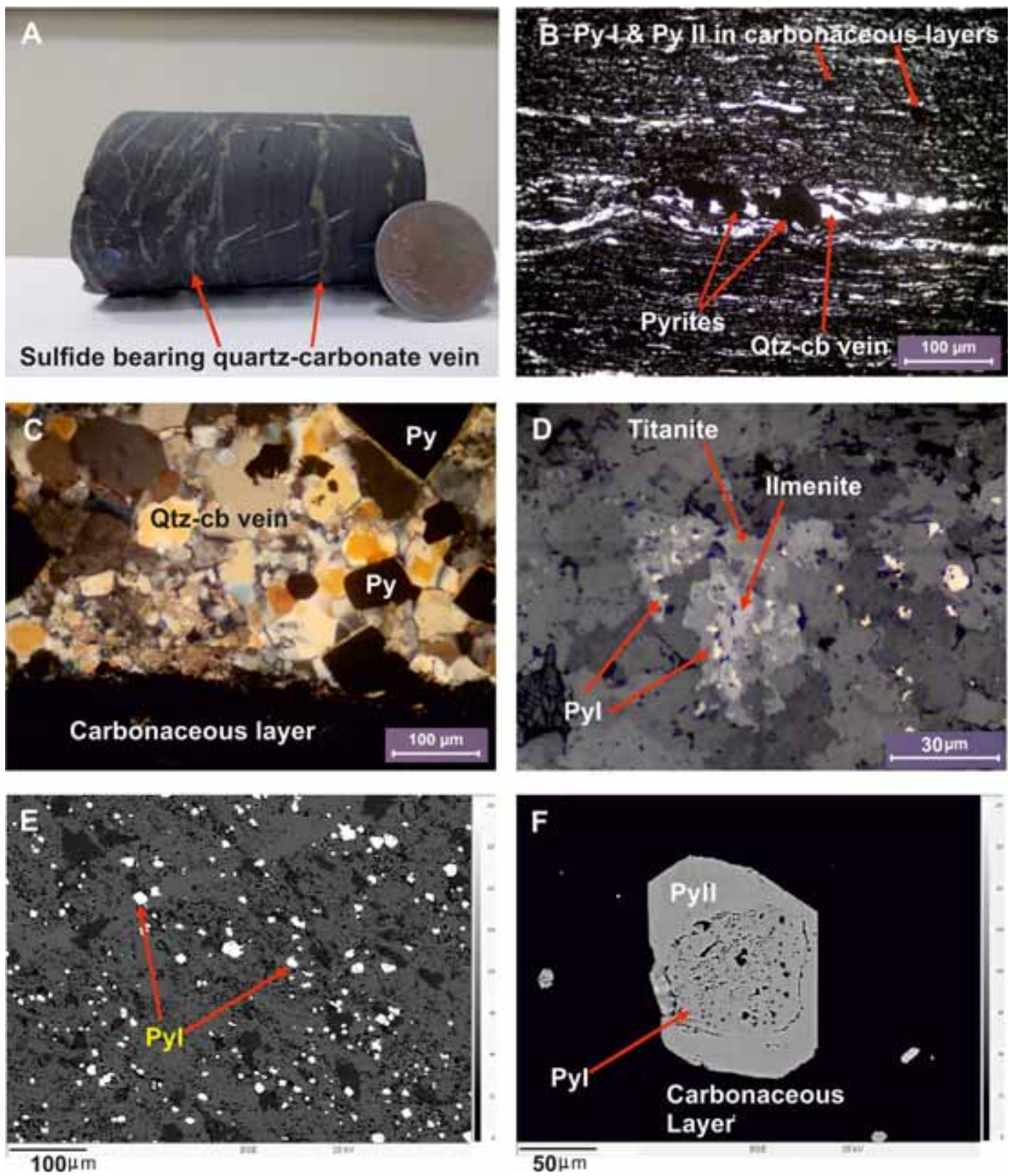

Figure 3. (a) Drill core sample of carbonaceous phyllite with numerous thin to thick sulphide-bearing quartz-carbonate veins; photomicrographs in PPL showing: (b) pyrite-bearing quartz-carbonate vein (qtz-cb vein) present in the carbonaceous phyllite and pyrites within the laminated carbonaceous layers; (c) dynamic recrystallisation of quartz within quartz-carbonate veins in carbonaceous phyllite; (d) photomicrograph in reflected light showing: Pyrite (Py I)-replacing ilmenite (Ilm), which is surrounded by titanite; BSE images showing: (e) Microcrystals of diagenetic pyrite within the carbonaceous laminations of phyllite and (f) diagenetic pyrite (Py I) with porous texture filled with quartz, carbonates within the carbonaceous layers of carbonaceous phyllite overgrown with hydrothermal pyrite (Py II).

within the carbonaceous phyllite. The mineralised veins show the dynamic recrystallisation of quartz due to deformation after emplacement (figure 3c). Pyrite is the dominant sulphide mineral in the vein followed by pyrrhotite and moderate to minor quantities of chalcopyrite, sphalerite, galena and arsenopyrite and these occur in association with each other (Majumdar et al. 2017). The occurrence of ilmenite has also been observed in the carbonaceous phyllites of the study area. Ilmenite generally gets altered to $\mathrm{Ti}$ oxides such as titanite, rutile by the pore fluids in the protoliths of the metapelitic rocks (Morad and Aldahan 1986; Calvert et al. 1996; Anjos et al. 2010; Cabral et al. 2013). The replacement of ilmenite by titanite is seen and ilmenite was later replaced with pyrite I (Py I) (figure 3d). 
Four types of pyrites were identified on the basis of their texture, morphology and trace-element concentrations. Py I is preferentially concentrated along the carbonaceous bands of the phyllites and occurs in two forms. The first variety of Py I occurs in the form of individual microcrystals that range from 0.5 to $27 \mu \mathrm{m}$ (figure $3 \mathrm{e}$ ). These pyrites are non-porous and do not contain any inclusions. The other variety of Py I is porous in nature, varies in size from 10 to $80 \mu \mathrm{m}$ and the pores are filled with quartz, carbonates and black carbonaceous matter. These rounded to subrounded pyrite grains occur in the core of Pyrite II (Py II) and independent varieties of these pyrites (Py II) have not been observed (figure 3f). The first variety of Py I is more abundant than that of the porous variety (figure $4 \mathrm{a}$ and b). The two varieties of Py I are considered to be of the same origin. Py II occurs as subhedral grains and its size ranges from 40 to $150 \mu \mathrm{m}$ (figure 3f) and is of different origins, which is well evident from its trace elemental composition. Both Py I and Py II occur along the carbonaceous laminations as disseminated grains in carbonaceous phyllites.

Two types of pyrrhotites have been observed based on the texture and morphology. The first type of pyrrhotite (Po I) is interspersed within carbonaceous matter, occurs as lath-shaped and microcrystals similar to that of the first variety of Py I (figure 4c). Po I also occurs as porous and rounded to subrounded grains similar to that of the porous variety of Py I (figure $4 \mathrm{~d}$ ). The second type of pyrrhotite occurs only in quartz \pm carbonate veins. Pyrrhotite (Po II) of second generation is present in quartz \pm carbonate veins, which also contain pyrite III. At certain places chalcopyrite (Ccp I) replaces Po II in these veins (figure 4e). Pyrrhotite (Po III) also occurs in quartz \pm carbonate veins containing Py IV.

Pyrite III (Py III) is coarse grained, anhedral to subhedral in shape and occurs only in quartz \pm carbonate veins (figure 4f). The presence of fractures within Py III (0.2-2.7 $\mathrm{mm}$ in size) indicates brittle deformation (figure $5 \mathrm{a}-\mathrm{c}$ ). Microinclusions of galena and silicates are present in Py III (figure 5d). A smaller size of Py III grains may be attributed to brittle deformation, which represent mylonitisation (figure 5e). Py I and II have also suffered deformation along with Py III (figures $4 \mathrm{~b}$ and 5f). Quartz strain fringes associated with Py III and the fractures in Py III illustrate that it has undergone a ductile-brittle deformational regime after its formation (figure 6a). At some places, $\mathrm{Py}$
III and Po II coexist and their grain boundary relationship suggests that these may have coprecipitated (figure 4f). Sphalerite inclusions (Sp I) within Py III suggest that these may have formed during the growth of Py III as Sp I is not associated with pyrites of earlier generations, viz., Py I and Py II (figure 6b). Sp I is less commonly found as compared to Py III. Chalcopyrite (Ccp I) coexists with Py III and occurs as small-anhedral grains (figure 6c). Arsenopyrite is also observed in association with Py III (figure 6d). Both Ccp I and arsenopyrite occur in lesser quantities.

Pyrite IV (Py IV) is subhedral to euhedral in shape and is devoid of fractures unlike Py III, which is highly fractured, suggesting that Py IV is the last pyrite to form in the phyllites (figure 5a). The size of Py IV varies from 0.12 to $1.6 \mathrm{~mm}$. Py IV precipitated along with the quartz and quartz-carbonate veins (figure 6e). The co-occurrence of Py III and Py IV at certain portions of the Py III-bearing veins has been explained in the 'Discussion' section (figure 5a). The presence of euhedral Py IV in the matrix of Po III suggests the co-crystallisation of these minerals (figure $6 \mathrm{f}$ ). Py IV is associated with rutile at some places (figure 6e). Py IV coexists with chalcopyrite (Ccp II) in the veins not consisting of Py III (figure 7a). Inclusions of sphalerite (Sp II) are present within $\mathrm{Py}$ IV, which have formed during the growth of $\mathrm{Py}$ IV (figure 5a). Both Sp II and Ccp II are less abundant compared to Py IV. Isolated grains of Py IV and the micro-inclusions of galena, silicates and carbonates in this pyrite are also the other common mineralogical associations (figure 6f). Galena occurs rarely as inclusions in Py IV, which might have formed during the growth of Py IV. Structural fabrics related to brittle deformation are dominated by micro-faults and is well evident from the presence of displaced quartz-carbonate veins, fractured pyrite grains and pronounced grain size reduction of the pyrites (figures $5 \mathrm{~b}$, e and $7 \mathrm{~b}$ ). Ductile shearing is marked by quartz strain fringes and boudinaged quartz-carbonate veins in carbonaceous phyllites (figures $6 \mathrm{a}$ and $7 \mathrm{c}$ ).

\section{Analytical techniques}

Detailed mineral chemistry of sulphide minerals was carried out using laser ablation-inductively coupled plasma mass spectrometry (LA-ICP-MS) in the Department of Geology and Geophysics, Indian Institute of Technology, Kharagpur, India. 

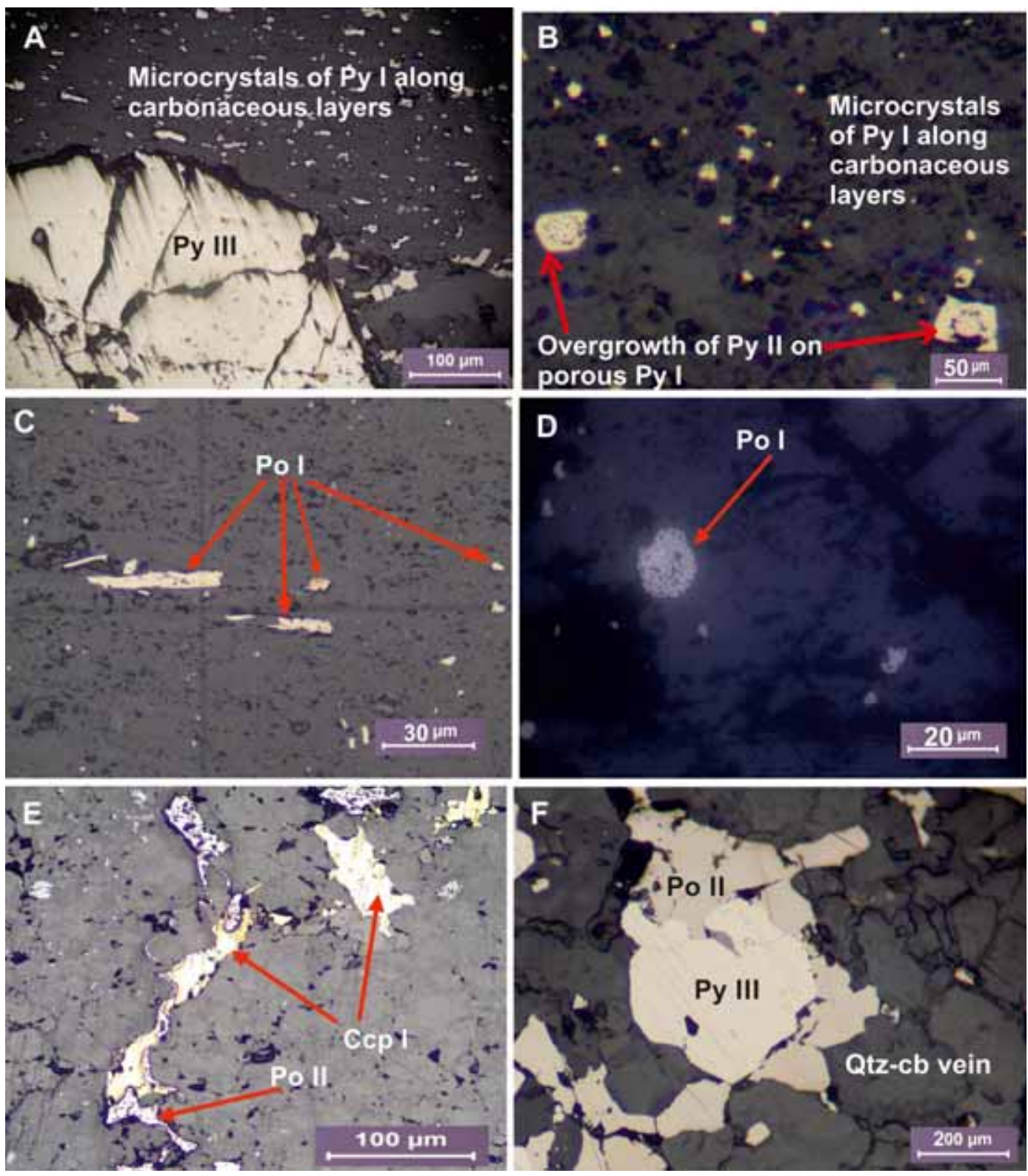

Figure 4. Photomicrographs in reflected light showing: (a) Microcrystals of Py I within the carbonaceous laminations of carbonaceous phyllite; (b) microcrystals of Py I, association of porous Py I and Py II within the carbonaceous laminations of carbonaceous phyllite; (c) pyrrhotite (Po I) interspersed with carbonaceous matter in the phyllite; (d) rounded pyrrhotite (Po I) within the carbonaceous laminations; (e) chalcopyrite (Ccp I)-replacing pyrrhotite (Po II) in quartz \pm carbonate veins and (f) deformed hydrothermal pyrite III (Py III) co-existing with pyrrhotite (Po II) within the quartz-carbonate veins (qtz-cb vein) of carbonaceous phyllites.

Trace-element concentrations were determined using a quadrupole ICPMS (ThermoFisher Scientific) coupled to a New Wave Research ESI 193 ArF Excimer laser ablation system. The ablation was performed at a pulse frequency of $5 \mathrm{~Hz}$, a spot size of 30-60 $\mu \mathrm{m}$ and a beam fluence of $4.5 \mathrm{~J} / \mathrm{cm}^{2}$. Helium was used as the carrier gas and each spot analysis consisted of a $20 \mathrm{~s}$ background measurement with the laser turned off and $40 \mathrm{~s}$ peak signal measurement with the laser turned on conditions.
NIST 612 glass was used for calibration. Data sets were reduced using the Glitter ${ }^{\odot}$ software using $\mathrm{Fe}$ as an internal standard. The NIST 610 glass was analysed repeatedly to check analytical precision and instrumental drift which yielded relative standard deviation (RSD) of $<5 \%$ for $\mathrm{V}, \mathrm{Mn}, \mathrm{Zr}$, Mo, Ag, Sn, Ba, La, Au, Tl, Th, Cr, Ti, Co, Ni, Cu and $\mathrm{Zn}$ and $<7 \%$ for $\mathrm{Pb}, \mathrm{W}$ and $\mathrm{U}$. Therefore, NIST glass standards can be considered homogeneous for trace element analysis as the relative standard 

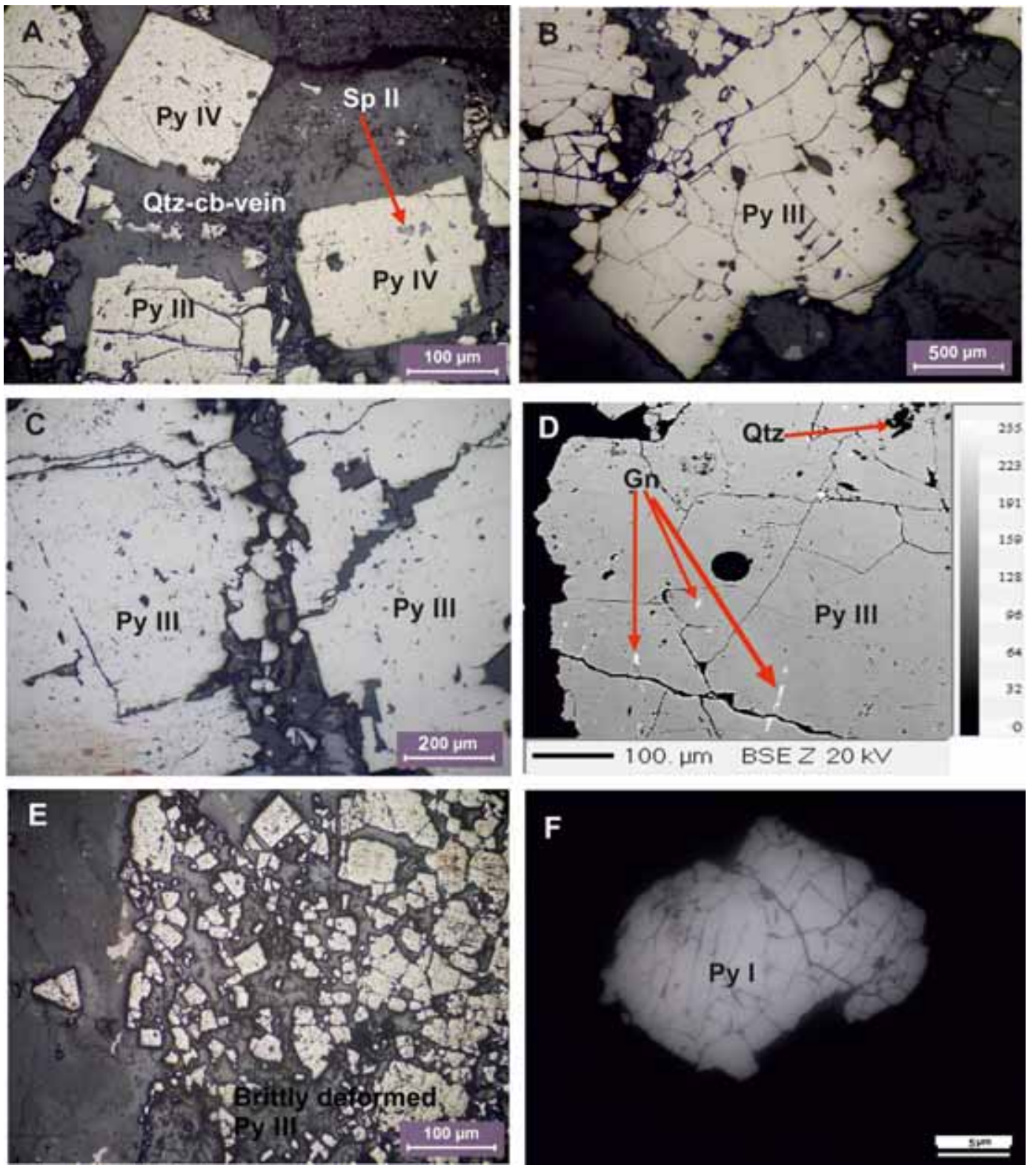

Figure 5. Photomicrographs in reflected light showing: (a) Fractured hydrothermal pyrite III and euhedral pyrite IV within the quartz-carbonate veins; (b) brittle deformed Py III with the development of a number of sealed fractures; (c) fractured pyrite grains due to crushing along their margins during deformation; BSE image showing: (d) Galena (Gn) and silicate (Qtz) inclusions along microfractures of pyrite III; photomicrographs in reflected light showing: (e) brittly deformed pyrite III (Py III) within the quartz-carbonate veins and (f) fractured Py I.

deviation is typically better than $5 \%$ for most of the elements (Wood and Kiseeva 2015). Earlier studies have also illustrated that effects due to dissimilarity in the matrix are negligible with a $193 \mathrm{~nm}$ wavelength, ns laser (Sylvester 2008; YongSheng et al. 2013).

The X-ray mapping of pyrite was carried out using a CAMECA SX 5 electron probe micro analyser in the Central Research Facility (CRF), Indian Institute of Technology (Indian School of Mines), Dhanbad, India to understand elemental distribution and the presence of zoning.
Quantitative data on Py I were obtained using a CETAC Nd:YAG $213 \mathrm{~nm}$ LA system coupled with an Agilent 7700 inductively coupled plasma mass spectrometer-quadrupole (ICPMS (QP)) at GSI, Faridabad, India. The ablation was performed at a spot size of $20-25 \mu \mathrm{m}$ and the USGS sulphide standard MASS-1 was used for calibration. The BCR-2G was analysed repeatedly to check analytical precision and instrumental drift which yielded an RSD of $<5 \%$.

For Fourier transform infrared (FTIR) analysis, whole-rock samples were subjected to $\mathrm{HCl}-\mathrm{HF}-$ 

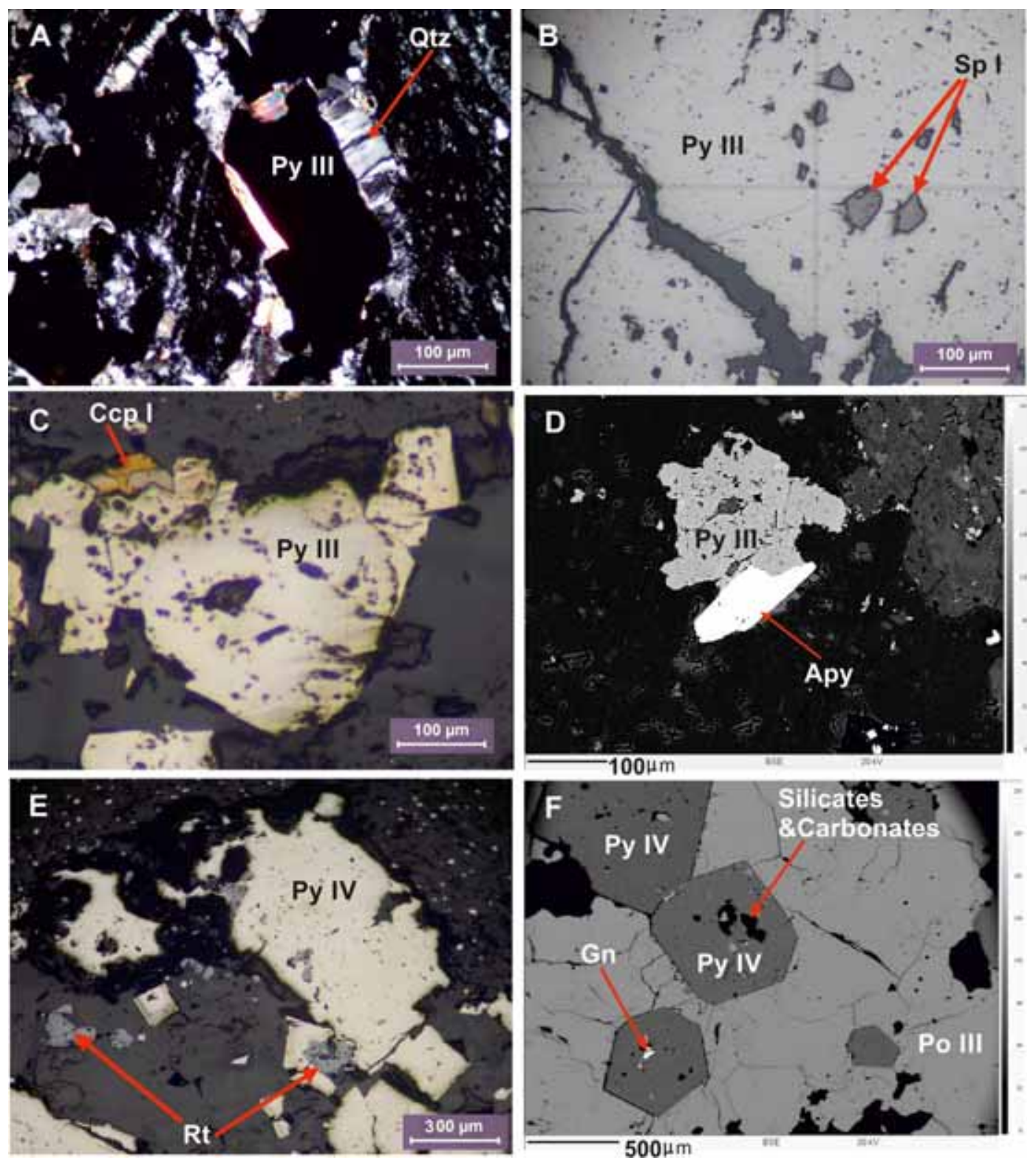

Figure 6. Photomicrograph in transmitted light showing: (a) Pyrite (Py III) with quartz (Qtz) strain fringes in carbonaceous phyllite; photomicrographs in reflected light showing: (b) Sphalerite (Sp I) inclusions within Py III; (c) association of chalcopyrite (Ccp I) with Py III indicating the co-precipitation of these two minerals; BSE image showing: (d) association of arsenopyrite (Apy) with Py III; photomicrograph in reflected light showing: (e) Pyrite IV along with rutile (Rt) present within the quartz-calcite vein and surrounded by disseminated pyrites of the carbonaceous layer and BSE image showing: (f) association of pyrrhotite (Po III) and Py IV indicating their co-crystallisation and microinclusions of galena, silicates and carbonates within pyrite IV.

$\mathrm{HCl}$ digestion to collect the carbonaceous material using the method of kerogen separation (Durand and Nicaise 1980). IR spectra were recorded using a Bruker spectrometer coupled to a 3000 Hyperion microscope with a Vertex 80 FTIR system at SAIF, IIT Bombay and reported in transmittance units as a function of the wave number $\left(\mathrm{cm}^{-1}\right)$ in the range of $4000-450 \mathrm{~cm}^{-1}$. The spectral band assignment was chosen after Caplan and Bustin (1998), Pitcairn et al. (2005) and Khodary et al. (2014).

\section{Mineral chemistry of pyrite}

Different generations of pyrites were analysed using LA-ICP-MS. The trace element data of pyrite and other sulphide grains are presented in tables 1 and 2. Fe and S contents in all the generations of pyrites vary from 45.1 to $45.99 \mathrm{wt} \%$ and 52.14 to $54.13 \mathrm{wt} \%$, respectively. The arsenic and invisible gold contents for Py I vary from 108.63 to $6032.68 \mathrm{ppm}$ and 0.01 to $3.24 \mathrm{ppm}$, respectively 

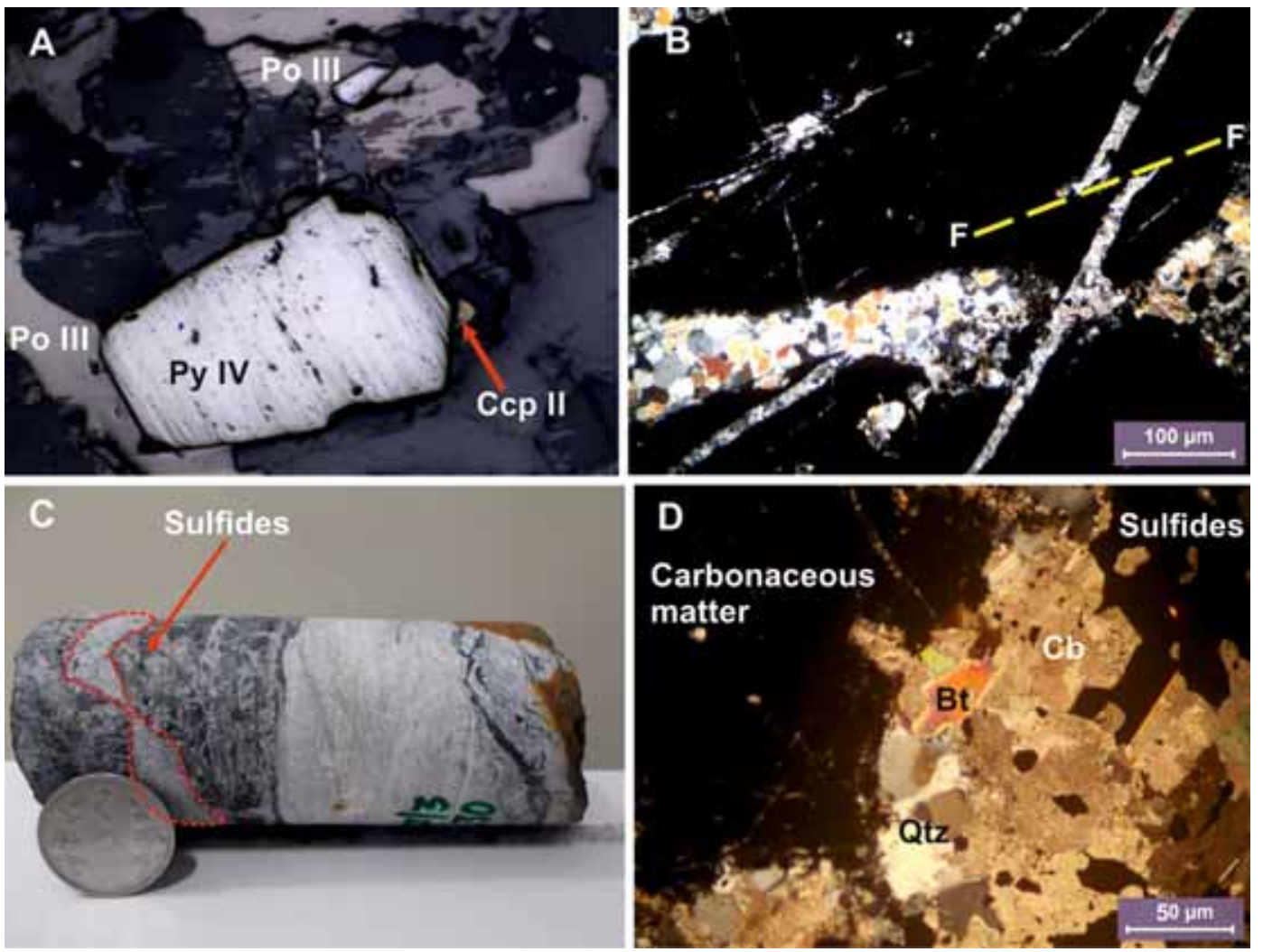

Figure 7. Photomicrograph in reflected light showing: (a) Chalcopyrite (Ccp II) in association with Py IV; photomicrograph in transmitted light showing: (b) Microfaults as evidenced by displaced quartz-carbonate veins in carbonaceous phyllite; (c) boudinaged quartz-carbonate veins in carbonaceous phyllites and photomicrograph in transmitted light showing: (d) Mineral assemblage of quartz, carbonates and biotite (Bt) in carbonaceous phyllites.

(table 1). Cobalt and nickel concentrations range from 75.51 to $1278.74 \mathrm{ppm}$ and 67.60 to 579.31 ppm, respectively. Py I has a very low $\mathrm{Co} / \mathrm{Ni}$ ratio (0.90-2.21), moderate quantities of $\mathrm{Zn}(7.12-$ $270.53 \mathrm{ppm}), \mathrm{Pb}(2.71-330.93 \mathrm{ppm})$ and $\mathrm{Cu}$ (0.2-140.69 ppm). These pyrites show low contents of Mo (0.36-18.98 ppm), Ag (0.25-12.6 ppm), $\mathrm{Zr}$ (0.11-20.19) and Bi (0.13-5.37 ppm). The concentration of $\mathrm{Ti}, \mathrm{V}, \mathrm{Cr}$ and $\mathrm{Mn}$ ranges from 0.57 to $115.14 \mathrm{ppm}, 0.66$ to $234.23 \mathrm{ppm}, 2.87$ to $88.84 \mathrm{ppm}$ and 1.84 to $59.07 \mathrm{ppm}$, respectively. Trace elements such as Sn, La, Tl and U show relatively lower concentrations as compared to other trace elements.

Py II, Py III and Py IV contain a wider range of trace elements such as Ti, V, Cr, Mn, Co, Ni, Cu, $\mathrm{Zn}, \mathrm{As}, \mathrm{Zr}, \mathrm{Mo}, \mathrm{Ag}, \mathrm{Sn}, \mathrm{Ba}, \mathrm{La}, \mathrm{W}, \mathrm{Au}, \mathrm{Tl}, \mathrm{Pb}$, Th, $\mathrm{U}$ and $\mathrm{Bi}$ as analysed by LA-ICP-MS (table 2). The arsenic concentrations of Py II (0.997 to 1.309 wt\% of As) and Py III (0.643 to $3.019 \mathrm{wt} \%$ of As) are greater than that of Py I. The invisible gold content of Py II varies from 6.88 to $55.5 \mathrm{ppm}$ and that of Py III from 2.05 to $110.55 \mathrm{ppm}$. Py IV is depleted in $\mathrm{Au}(0.06-6.7$ ppm). These pyrites (Py II, Py III and Py IV) are characterised by varying $\mathrm{Co}$ and $\mathrm{Ni}$ contents ranging from 101.23 to $5877.5 \mathrm{ppm}$ and 110.3 to $2044.57 \mathrm{ppm}$, respectively. The $\mathrm{Co} / \mathrm{Ni}$ ratios of $\mathrm{Py}$ II, Py III and Py IV range from 0.98 to $10.2,0.26$ to 11.14 and 0.51 to 12.79 , respectively (figure 8 ). Py II consists of a considerable quantity of $\mathrm{Zn}$ (5.65-500.69 ppm), Cu (6.67-830.21 ppm), Mo (0.06-260.1 ppm) and moderately high concentrations of $\mathrm{Pb}$ (1.32-1267.93 ppm). The concentration of $\mathrm{Ag}$ in $\mathrm{Py}$ II varies from 0.29 to 10.65 ppm. Copper (2.8-1275.81 ppm), Zn (3.47$1457.08 \mathrm{ppm})$ and $\mathrm{Pb}(6.94-2978.77 \mathrm{ppm})$ contents show large variations with relatively higher concentrations in Py III. Py III contains relatively lower concentrations of Mo (0.35-120.5 $\mathrm{ppm})$ and $\mathrm{Ag}(0.4-20.33 \mathrm{ppm})$. These pyrites of different generations have low $\mathrm{Ti}$ and $\mathrm{Bi}$ signatures. Elements such as V, Cr, Mn, Zr, Sn, Ba, La, W, Tl, Th and U show marked depletion in Py II, Py III and Py IV. Py IV has the least concentration of $\mathrm{Pb}(0.93-222.24 \mathrm{ppm}), \mathrm{Cu}(0.78-75.84$ ppm), Zn (5.92-21.2 ppm), As (392.82-6118.88 $\mathrm{ppm})$, Mo (0.07-37.5 ppm) and Ag (0.33-2.54 ppm) with respect to that of Py II and Py III. 
Table 1. Mineral chemistry of diagenetic pyrite (Py I) in carbonaceous phyllites of SPSZ using $L A-I C P-M S$ (in ppm). Fe and S data were obtained by EPMA in wt\%.

\begin{tabular}{|c|c|c|c|c|c|c|c|c|}
\hline Mineral & Py I & Py I & Py I & Py I & Py I & Py I & Py I & Py I \\
\hline $\mathrm{Ti}$ & BDL & BDL & 0.57 & 13.71 & 115.14 & BDL & 85.81 & 111.24 \\
\hline V & 1.12 & BDL & BDL & 8.06 & 234.23 & 0.66 & 194.11 & 134.17 \\
\hline $\mathrm{Cr}$ & 9.74 & 22.93 & 7.74 & 34.39 & 88.84 & 2.87 & 24.19 & 74.06 \\
\hline Mn & 4.97 & 1.84 & 5.89 & 5.77 & 59.07 & 6.57 & 46.44 & 56.37 \\
\hline $\mathrm{Co}$ & 112.56 & 113.93 & 250.90 & 75.51 & 626.58 & 269.33 & 1278.74 & 144.50 \\
\hline $\mathrm{Ni}$ & 87.25 & 97.76 & 129.83 & 67.60 & 310.62 & 252.38 & 579.31 & 160.28 \\
\hline $\mathrm{Cu}$ & 5.86 & BDL & 8.10 & 0.20 & 0.79 & 3.36 & 140.69 & 80.83 \\
\hline $\mathrm{Zn}$ & 12.50 & BDL & BDL & 7.12 & 54.11 & BDL & 14.87 & 270.53 \\
\hline As & 205.30 & 200.78 & 435.51 & 108.63 & 6032.68 & 733.68 & 1136.53 & 270.82 \\
\hline $\mathrm{Zr}$ & 0.11 & 0.000 & 3.70 & 0.000 & 0.33 & 20.19 & 0.55 & 0.22 \\
\hline Мо & 0.59 & 5.23 & 0.89 & 14.56 & 18.98 & 0.000 & BDL & 0.36 \\
\hline $\mathrm{Ag}$ & 5.69 & 0.65 & 2.89 & 0.85 & 12.56 & 0.25 & 1.22 & 9.47 \\
\hline $\mathrm{Sn}$ & BDL & 1.41 & BDL & 1.41 & BDL & 0.05 & 0.85 & 0.73 \\
\hline $\mathrm{La}$ & 0.000 & 0.000 & 0.03 & 0.000 & 0.000 & 0.000 & 0.000 & 0.000 \\
\hline $\mathrm{W}$ & 0.000 & 0.000 & 0.000 & 0.000 & 0.000 & BDL & 0.000 & BDL \\
\hline $\mathrm{Au}$ & 0.33 & 0.00 & 0.12 & BDL & 3.24 & 0.00 & 0.01 & 1.75 \\
\hline $\mathrm{Tl}$ & 0.20 & 0.33 & BDL & 0.34 & BDL & BDL & 0.22 & 0.40 \\
\hline $\mathrm{Pb}$ & 7.66 & 3.83 & 2.71 & 3.52 & 17.16 & 39.54 & 330.93 & 22.96 \\
\hline Th & BDL & 0.000 & 0.000 & 0.000 & BDL & 0.000 & BDL & 0.000 \\
\hline $\mathrm{U}$ & 0.000 & BDL & 0.21 & 0.000 & 0.000 & 0.000 & BDL & 0.03 \\
\hline $\mathrm{Fe}$ & 45.69 & 45.79 & 45.99 & 45.69 & 45.7 & 45.72 & 45.75 & 45.64 \\
\hline $\mathrm{S}$ & 52.77 & 53.15 & 53.33 & 54.03 & 53.2 & 52.78 & 53.55 & 53.44 \\
\hline $\mathrm{Bi}$ & 0.31 & 0.51 & 0.13 & 0.16 & 5.370 & 1.63 & 0.92 & 1.16 \\
\hline $\mathrm{Co} / \mathrm{Ni}$ & 1.29 & 1.17 & 1.93 & 1.12 & 2.02 & 1.07 & 2.21 & 0.90 \\
\hline
\end{tabular}

\section{Organic matter characterisation using FTIR}

The FTIR spectrum of carbonaceous matter, which was separated from carbonaceous phyllite, shows multiple functional groups (figure 9). A broad band around $3424.62 \mathrm{~cm}^{-1}$ is due to the $\mathrm{O}-\mathrm{H}$ stretching vibrations $v\left(\mathrm{OH}_{2}\right)$. Asymmetric and symmetric stretching of the aliphatic methyl $\left(\mathrm{CH}_{3}\right)$ and methylene groups $\left(\mathrm{CH}_{2}\right)$ are represented by the spectral lines at 2922.34 and $2852.85 \mathrm{~cm}^{-1}$, respectively. The bending vibrations of $\mathrm{CH}_{3}$ and $\mathrm{CH}_{2}$ are observed at 1367.83 and $1453.61 \mathrm{~cm}^{-1}$, respectively. The peak at $1741.44 \mathrm{~cm}^{-1}$ is due to the stretching vibrations of the carbonyl group $(\mathrm{C}=\mathrm{O})$. Spectral lines at $1637.79 \mathrm{~cm}^{-1}$ are related to either the alkene $(\mathrm{C}=\mathrm{C})$ double bond stretching regions or the $\mathrm{OH}$ molecule bending vibrations. The stretching vibrations of the $\mathrm{C}-\mathrm{O}$ bond are demarcated at 1215.10 and $1039.84 \mathrm{~cm}^{-1}$. The presence of $\mathrm{C}-\mathrm{H}$ stretching vibrations of the methyl and methylene group itself indicates that the carbonaceous matter present in the phyllites is organic. The multiple functional groups of organic matter are possibly due to the differential maturation of the organometallic compounds/organic matter during metamorphism and deformation.

\section{Discussion}

\subsection{Origin of pyrite}

The origin of pyrite can be inferred from the $\mathrm{Co} / \mathrm{Ni}$ ratio. It further leads to the identification of ore deposit type (Hawley and Nichol 1961; Loftus-Hills and Solomon 1967; Giri et al. 2018). The X-ray elemental maps of $\mathrm{Co}$ and $\mathrm{Ni}$ of different generations of pyrites in the carbonaceous phyllite shows that these elements are homogeneously distributed in the crystal lattice of the pyrites (figure 10). The intimate association of the microcrystal and rounded to subrounded porous variety of Py I with the organic matter in the phyllites and the $\mathrm{Co} / \mathrm{Ni}$ ratio (0.90-2.20), suggest that Py I is of sedimentary origin (Large et al. 2014; Gregory et al. 2015). The $\mathrm{Co} / \mathrm{Ni}$ ratios of Py II (0.98-10.2), Py III (0.26-11.14) and Py IV (0.51-12.79) are highly 


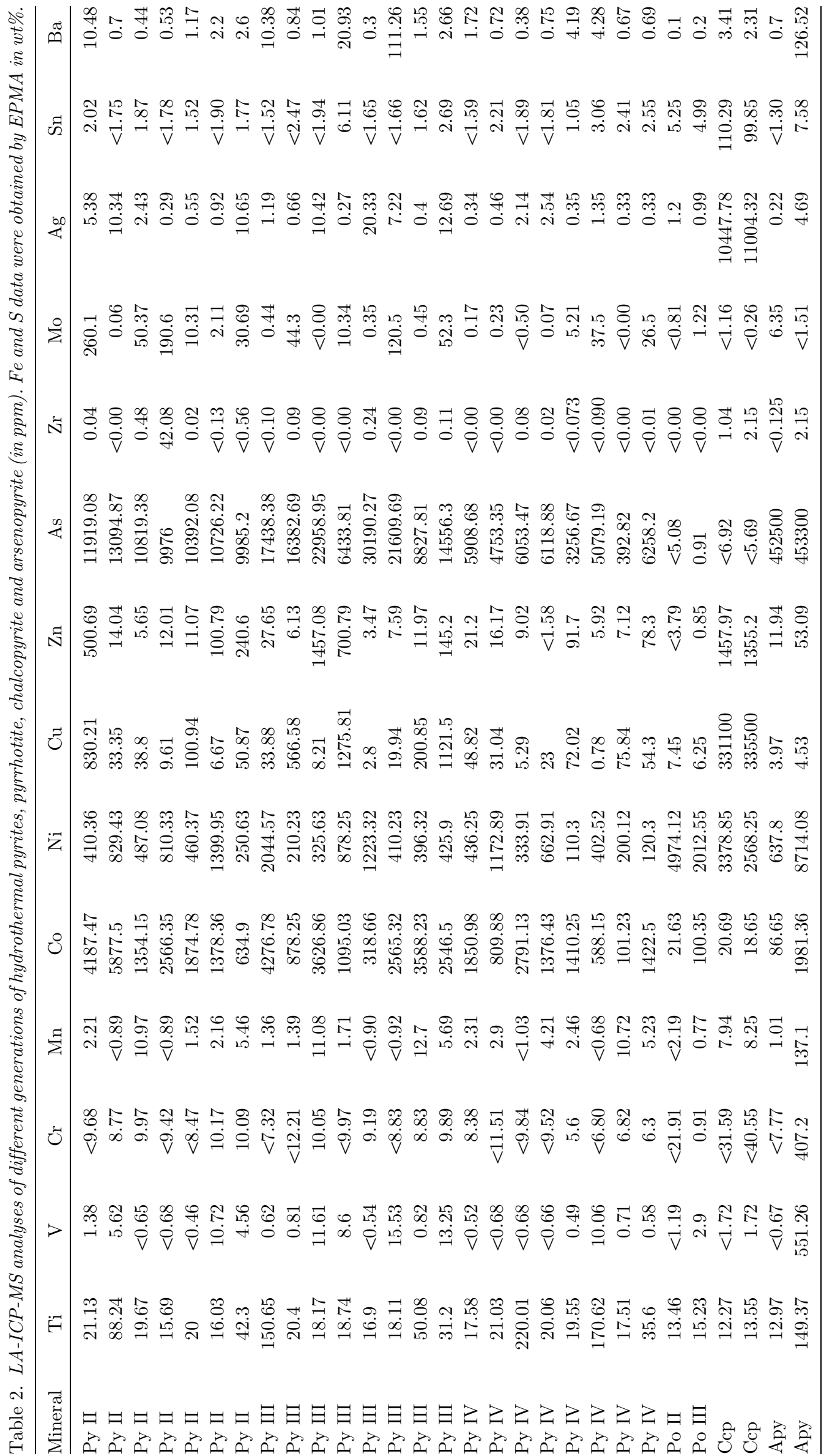




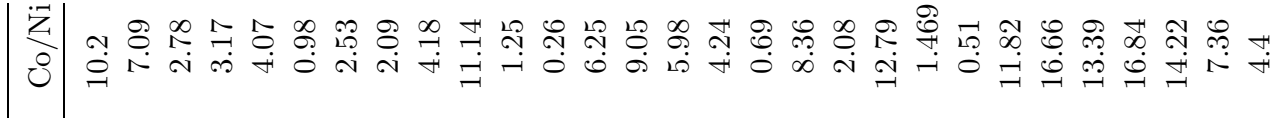

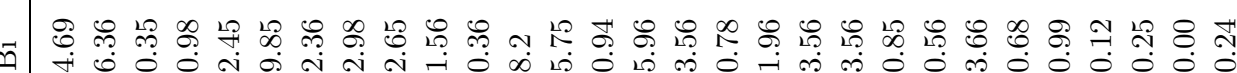

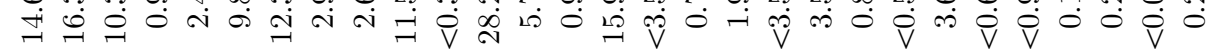

๙

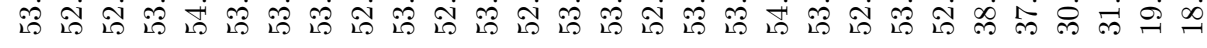

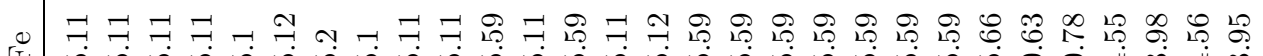

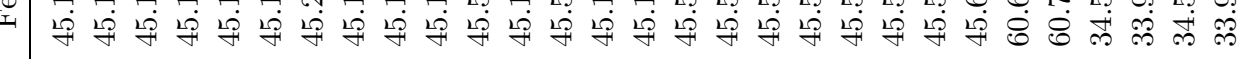

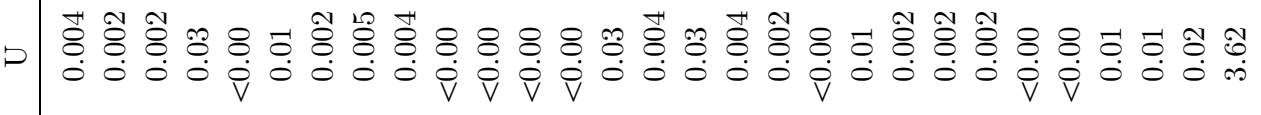

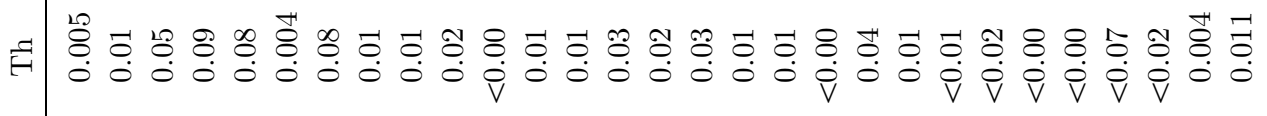

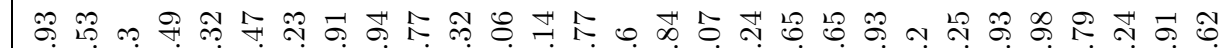

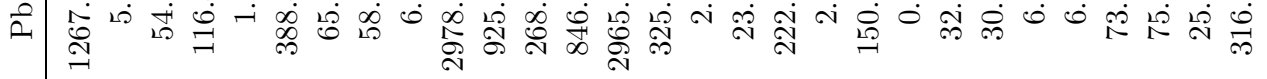

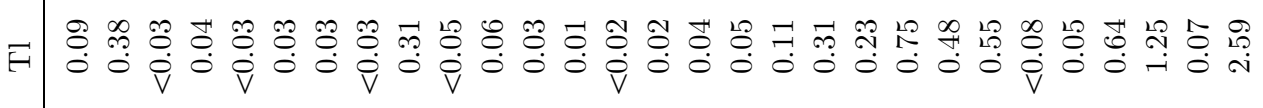

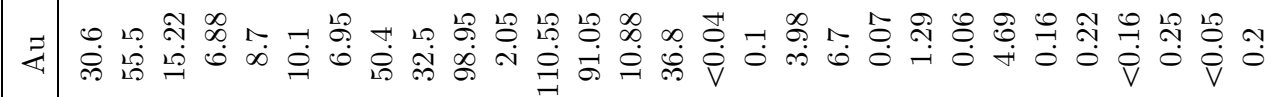

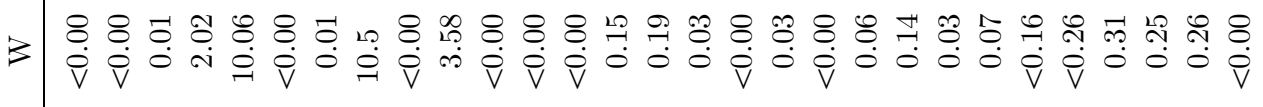

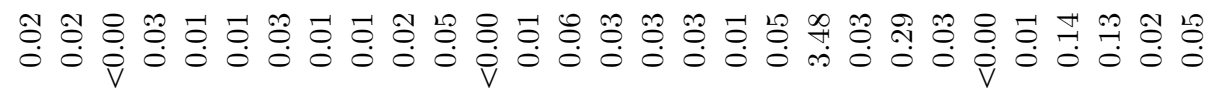



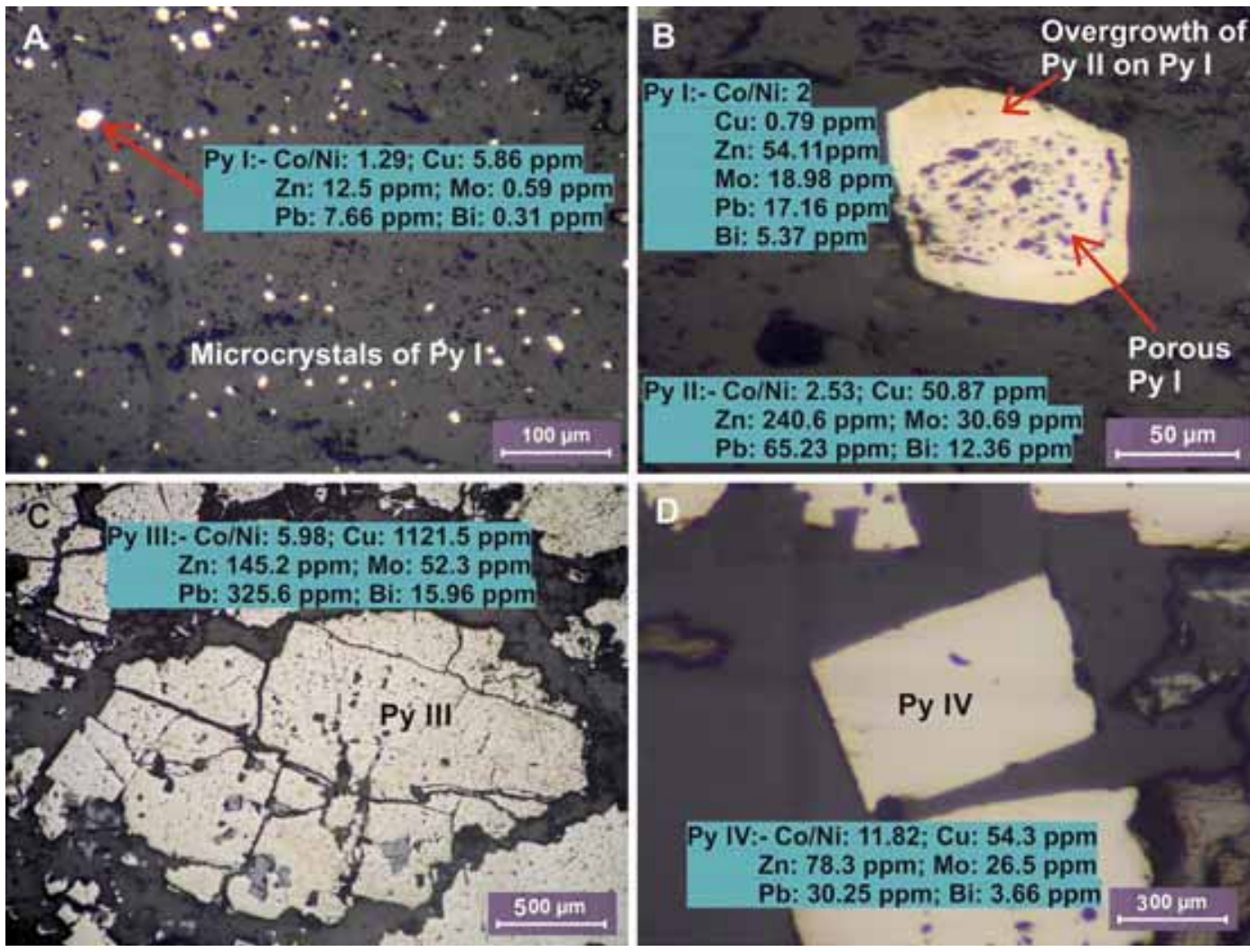

Figure 8. Trace elemental concentrations ( $\mathrm{Cu}, \mathrm{Zn}, \mathrm{Mo}, \mathrm{Pb}, \mathrm{Bi})$ and $\mathrm{Co} / \mathrm{Ni}$ ratios of: (a) Microcrystal variety of Py I; (b) porous variety of Py I and Py II; (c) Py III and (d) Py IV.

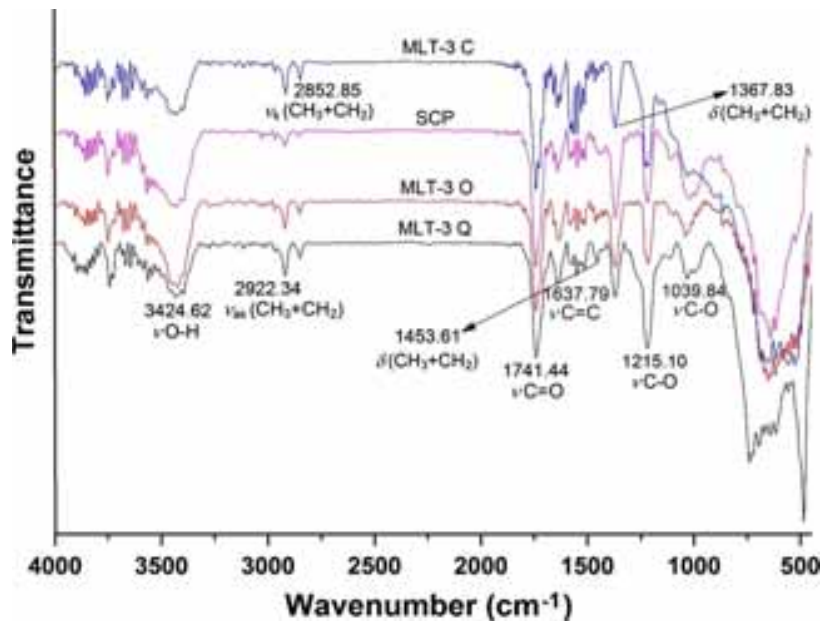

Figure 9. FTIR spectra of organic matter in carbonaceous phyllites (MLT-3 C, SCP, MLT-3 O and MLT-3 Q) of SPSZ.

variable and mostly $>1$, which suggest their hydrothermal origin (Bralia et al. 1979; Cook 1996; Zhao et al. 2011). Py III and Py IV are confined to the quartz-carbonate veins whereas Py II occurs as an overgrowth on the porous variety of Py I, which might be due to the interaction of ore-bearing fluids with Py I by percolating into the carbonaceous laminations of the phyllites.

\subsection{Trace elements of pyrite}

Trace elements in pyrite generally occur in various forms viz., (i) in solid solution, (ii) as sub-micrometre inclusions of minerals, (iii) within visible micro-inclusions of other sulphides and (iv) within visible micro-inclusions of silicate or carbonate minerals (Large et al. 2011; Thomas et al. 2011). As pyrite has the ability to incorporate trace metals such as $\mathrm{Au}, \mathrm{Ni}, \mathrm{Co}, \mathrm{Cu}, \mathrm{Zn}, \mathrm{As}$, $\mathrm{Mo}, \mathrm{Ag}, \mathrm{Te}, \mathrm{Pb}$ and $\mathrm{Bi}$ in detectable quantities (Deditius et al. 2011; Reich et al. 2013), pyrites of different generations in the carbonaceous phyllites can be studied to understand their chemical evolution mainly on the basis of trace-element concentrations. There is a pronounced difference in the trace-metal concentrations for different generations of pyrites in the study area.

The correlation between $\mathrm{Co}$ and $\mathrm{Ni}$ of various generations of pyrites is shown in figure 11(a). The lower $\mathrm{Co} / \mathrm{Ni}$ ratios $(\leq 2.20)$ of Py I are ascribed to reducing conditions in environments rich in organic matter that favours the uptake of more Ni in Py I (Dill and Kemper 1990; Guy et al. 2010). The presence of $\mathrm{Ni}$ in sedimentary pyrites is unaffected by metamorphism and hydrothermal processes 

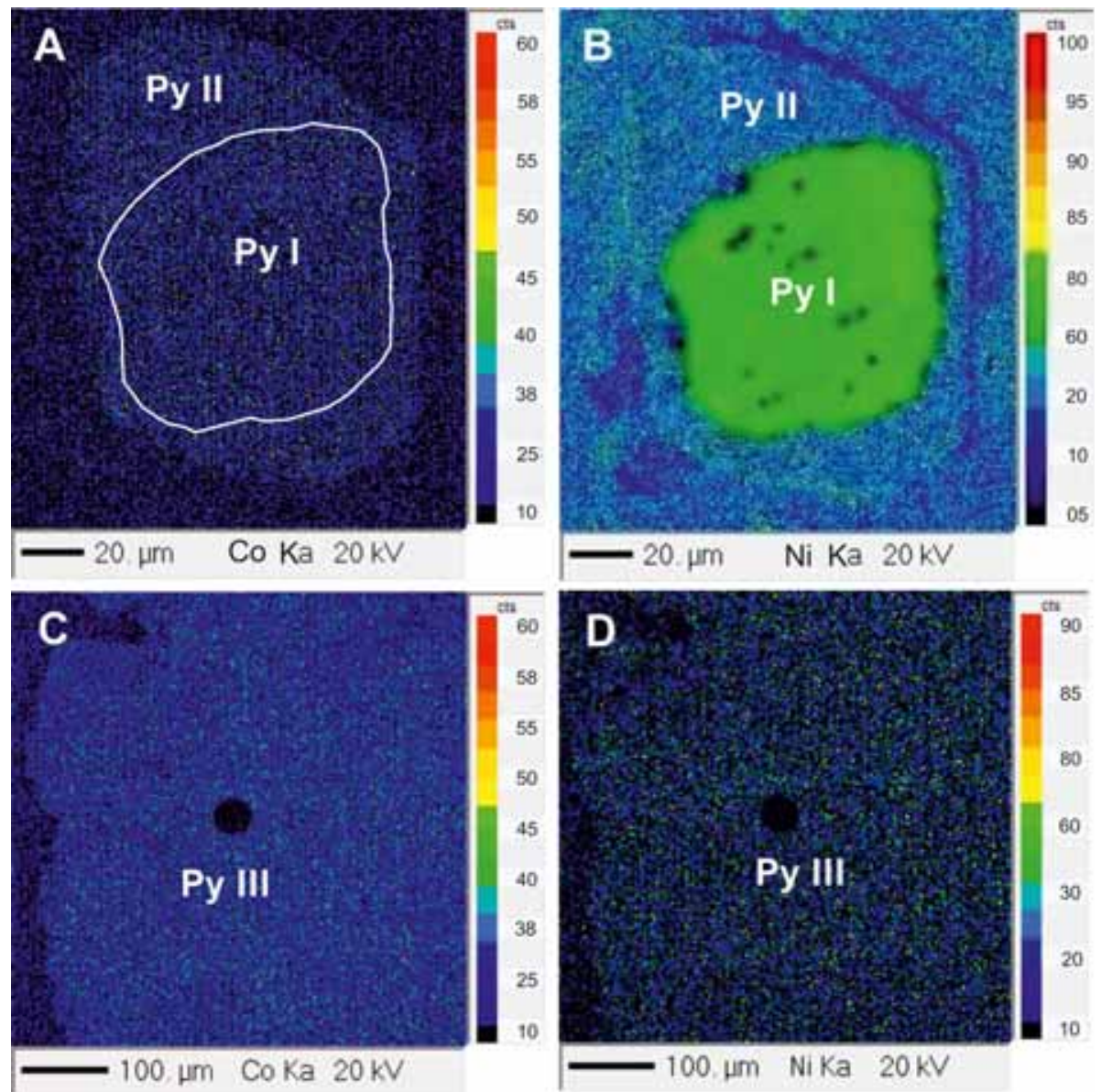

Figure 10. The X-ray elemental maps of $\mathrm{Co}$ and $\mathrm{Ni}$ of different generations of pyrites in the carbonaceous phyllite. The Co concentrations in these Py I (626.58 ppm) and Py II (634.9 ppm) are very similar whereas Ni concentrations are more in Py I (310.62 ppm) as compared to Py II (250.63 ppm).

(Large et al. 2007) and therefore it can be considered to represent the intrinsic concentrations. LAICP-MS studies indicate that different generations of pyrites contain significant concentrations of As. The concentration of As in the pyrites remains relatively constant with slightly higher concentrations in Py II and Py III. The higher concentration of As (mostly $>0.09$ wt\%) in the hydrothermal pyrites implies that these are arsenian pyrites (Reich et al. 2005). Pyrite from the study area shows negative correlation of As and S (figure 11b) and suggests a non-stoichiometric substitution of $\mathrm{As}^{-1}$ for $\mathrm{S}$ resulting in the formation of $\mathrm{AsS}^{3-}$ (Fleet and Mumin 1997; Abraitis et al. 2004; Deditius et al. 2008, 2009). This results in p-type semiconducting properties, observed in arsenian pyrite, which increases their electrochemical interaction with negatively charged ions (Mironov et al. 1981; Maddox et al. 1998). Arsenian pyrite, which exhibits p-type semiconducting properties form at relatively low temperatures as compared to n-type pyrites, which are deficient in As and are formed at higher temperatures (Abraitis et al. 2004). Metastable arsenian pyrite, which formed rapidly under disequilibrium conditions, provides surface defects and facilitates the incorporation of $\mathrm{Au}$ and other trace elements into its lattice (Cook and Chryssoulis 1990; Fleet and Mumin 1997; Wang and Zhu 2015).

Gold precipitates on the As-rich surface of arsenian pyrite by the adsorption-reduction of ore fluids enriched in $\mathrm{Au}$ or incorporated by adsorption during the growth of arsenian-pyrite crystals (Jean and Bancroft 1985; Hyland and Bancroft 1989; Simon et al. 1999). In the $\mathrm{Au}-\mathrm{As}$ correlation diagram given by Reich et al. (2005), pyrite samples plot below the gold solubility line, which suggests that $\mathrm{Au}$ in pyrite was incorporated in solid solution (Li et al. 2014). The LA-ICP-MS results from the study area reveal that the invisible gold within the diagenetic and hydrothermal pyrite occurs as lattice bound gold. Py II and Py III contain a 

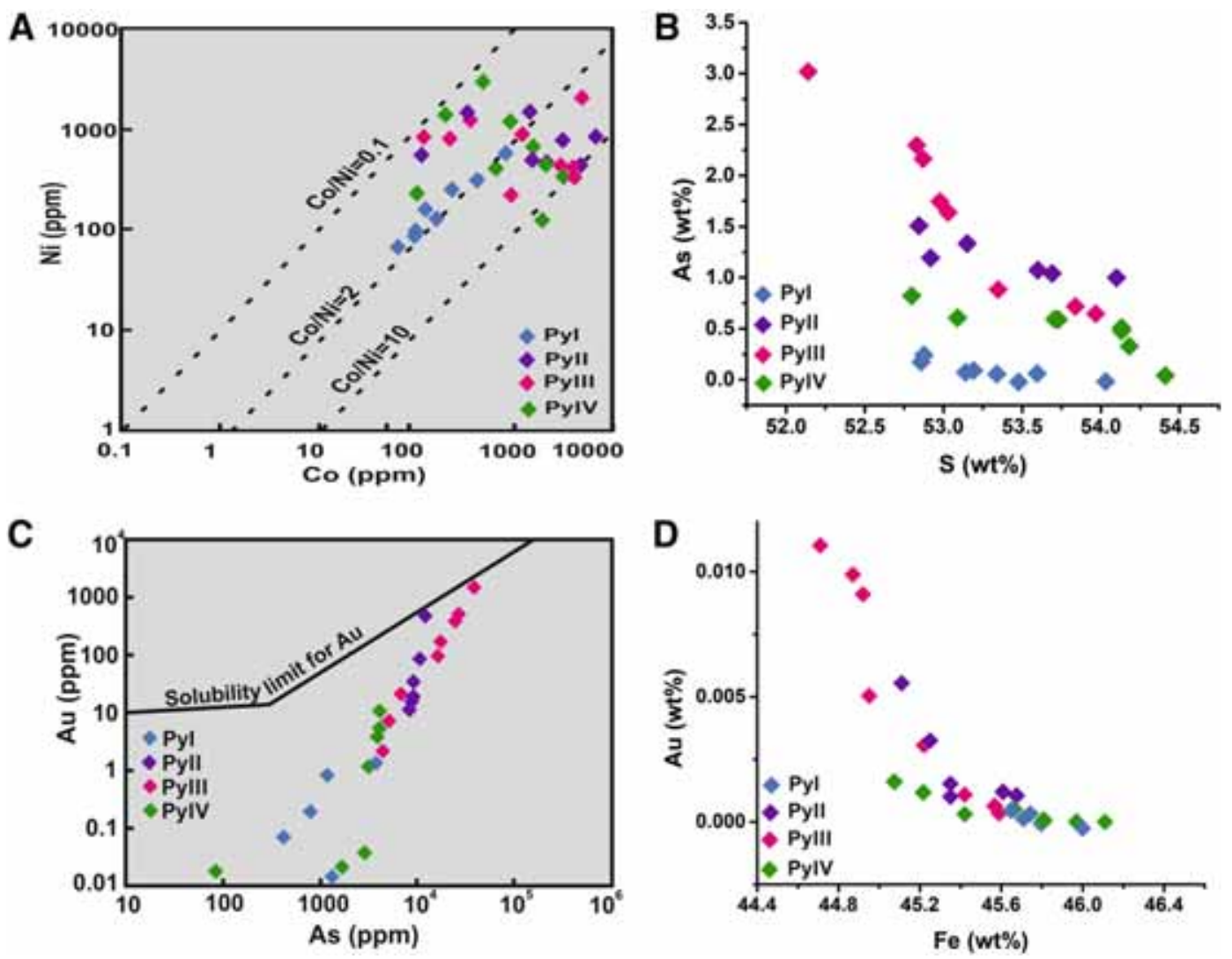

Figure 11. Correlation diagrams of various trace elements in different generations of pyrites: (a) The Co and Ni contents and $\mathrm{Co} / \mathrm{Ni}$ ratios; (b) negative correlation between As and $\mathrm{S}$ indicates replacement of $\mathrm{S}$ with $\mathrm{As}^{-1}$; (c) solubility limit of Au in pyrite as a function of As after Reich et al. (2005) and (d) negative correlation between Fe and Au implies that Au is replacing Fe ${ }^{2+}$.

higher concentration of invisible gold as compared to Py I. The negative correlation of $\mathrm{Au}$ and $\mathrm{Fe}$ concentrations indicates that $\mathrm{Au}$ has grown on the Fe-deficient pyrite surface or substituted $\mathrm{Fe}^{2+}$ as shown in figure 11(d) (Buerger 1936; Wood and Strens 1979; $\mathrm{Wu}$ and Delbove 1989; Cook and Chryssoulis 1990; Friedl et al. 1995; Fleet and Mumin 1997; Tarnocai et al. 1997). The positive correlation between $\mathrm{Au}$ and As suggests that the solubility of gold in the solid solution of pyrite is a function of As (figure 11c). It suggests that $\mathrm{Au}^{3+}$ substitutes $\mathrm{Fe}^{2+}$ and $\mathrm{AsS}^{3-}$ substitutes $\mathrm{S}_{2}{ }^{2-}$ in the pyrite lattice. The process is known as coupled substitution (Arehart et al. 1993; Huston et al. 1995; Abraitis et al. 2004). Hence As is a crucial factor which controls the concentration of $\mathrm{Au}$ in the pyrite structure (Reich et al. 2005).

The positive correlation between $\mathrm{Ni}$ and $\mathrm{Au}$ of the diagenetic pyrite shown in figure 12(a) suggests that $\mathrm{Ni}$ may have enhanced the intake of gold in the pyrite lattice (Large et al. 2009). The positive correlation between $\mathrm{Ag}$ and $\mathrm{Au}$ may be due to the coupling of the $\mathrm{Au}-\mathrm{Ag}$ transfer in the hydrothermal fluids or higher Ag concentration. Alternatively, Ag could have facilitated the incorporation of $\mathrm{Au}$, or vice versa in pyrites as they show a positive correlation (figure 12b).

The concentrations of $\mathrm{Cu}, \mathrm{Zn}, \mathrm{Mo}, \mathrm{Pb}$ and $\mathrm{Bi}$ are less in Py I as compared to the hydrothermal pyrites (figure 8) as these elements are weakly bonded within the pyrite lattice and get released during metamorphism, deformation and pressure solution processes to the hydrothermal fluids (Large et al. 2007). The presence of such metals in the pyrite lattice may be attributed to (i) the nanometer-scale inclusions of minerals or (ii) solid solution in the pyrite structure (Large et al. 2007, 2009, 2011; Cabral et al. 2011; Thomas et al. 2011). Deformational events are responsible for the fracturing and pulverising of $\mathrm{Py}$ III, which facilitated the hydrothermal fluid flow within it ( $c f$. Velasquez et al. 2014). This resulted in the local remobilisation of certain trace elements from the fractured Py III and was again reprecipitated in the form of other sulphides such as galena inclusions within the microfractures of hydrothermal Py III which is a common mechanism for the formation of such microinclusions during metamorphism and 

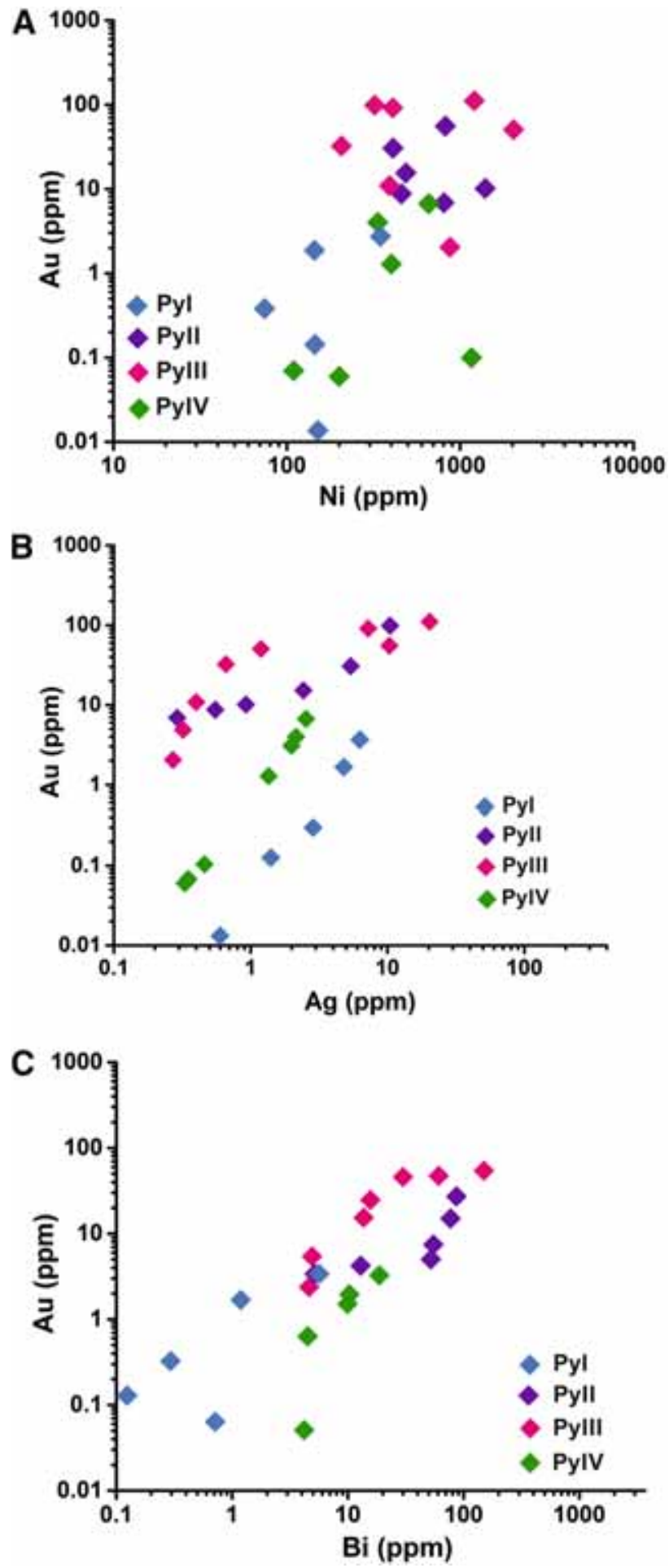

Figure 12. Correlation diagrams of various trace elements in different generations of pyrites: (a) Ni shows positive correlation with $\mathrm{Au}$ in diagenetic pyrite (Py I) and (b) and (c) $\mathrm{Au}$ shows positive correlation with $\mathrm{Ag}$ and $\mathrm{Bi}$.

hydrothermal circulation (Tomkins and Mavrogenes 2001; Sahoo and Venkatesh 2015; figure 5d). Moderate concentrations of $\mathrm{Ti}$ can be attributed to the occurrence of Ti in the pyrite lattice (Py III and Py IV). Rutile grains also occur in close association with the hydrothermal pyrite (figure 6e). Moderately high Mo contents in Py II and Py III lattices indicate that the hydrothermal fluid interacted with the carbonaceous host rocks as carbonaceous metasedimentary rocks are typically enriched with $\mathrm{Mo}(\mathrm{Li}$ et al. 2014). The lower concentrations of Mo in Py IV suggest that it precipitated from a hydrothermal fluid which comprised less Mo. This fluid may have interacted less with the carbonaceous metasedimentary rocks. Bismuth is present as a solid solution or micro inclusions of metals or sulphides (Large et al. 2007, 2009; Thomas et al. 2011). Bismuth concentrations also show a positive correlation comapred to those of $\mathrm{Au}$ (figure 12c). The hydrothermal fluids responsible for the precipitation of Py II, Py III and Py IV contained lower concentrations of $\mathrm{V}, \mathrm{Cr}, \mathrm{Mn}$, Zr, Sn, Ba, La, W, Tl, Th and U than that of Ti, Co, $\mathrm{Ni}, \mathrm{Cu}, \mathrm{Zn}, \mathrm{As}, \mathrm{Mo}, \mathrm{Ag}, \mathrm{Au}, \mathrm{Pb}$ and Bi.

\subsection{Role of organic matter}

Organic rich metasedimentary rocks act as a trap as well as a source of valuable elements such as Au, Ag and Bi (Large et al. 2011; Hazarika et al. 2013; Sahoo and Venkatesh 2014). The organic matter within carbonaceous metasedimentary rocks indicates reducing conditions favourable for the formation of diagenetic pyrites. During the formation of sedimentary pyrite, trace elements from the pore water are also adsorbed onto their surface. Organic matter and iron-rich minerals release trace elements such as $\mathrm{As}, \mathrm{Au}, \mathrm{Mo}, \mathrm{V}, \mathrm{Ni}, \mathrm{Se}, \mathrm{Pb}$ and $\mathrm{Cu}$ into the pore water, which are subsequently incorporated into the diagenetic pyrite during their growth in the organic muds (Tribovillard et al. 2006). The above-mentioned trace elements usually form organometallic bonds, which get partitioned into the organic matter from the sea water. The organic matter generates suitable redox conditions and likely facilitates the precipitation of hydrothermal pyrite within the quartz \pm carbonate veins. During prograde metamorphism and dehydration of hydrous minerals such as chlorite and muscovite, carbonaceous pelitic rocks containing sulphides are the most favourable rock types for the generation of sulphurous fluids (Tomkins 2010). Organic carbon, Fe in silicates or carbonates and metamorphic water promote the conversion of diagenetic pyrite to pyrrhotite as given by the following reactions (Thomas et al. 2011):

$$
2 \mathrm{FeS}_{2}+2 \mathrm{H}_{2} \mathrm{O}+\mathrm{C} \rightarrow 2 \mathrm{FeS}+2 \mathrm{H}_{2} \mathrm{~S}+\mathrm{CO}_{2}
$$


and

$$
\begin{aligned}
& \mathrm{FeS}_{2}+\mathrm{Fe}^{2+}+0.5 \mathrm{C}+\mathrm{H}_{2} \mathrm{O} \\
& \rightarrow 2 \mathrm{FeS}+2 \mathrm{H}^{+}+0.5 \mathrm{CO}_{2} .
\end{aligned}
$$

This conversion process during greenschist and lower amphibolite facies metamorphic transition led to the liberation of different trace elements and especially $\mathrm{Au}$ as the soluble bisulphide complex into the metamorphic fluid.

\subsection{Evolutionary stages of pyrites}

The carbonaceous phyllites of the study area are characterised by the presence of multistage pyrites. The evolutionary stages of pyrites have been studied in detail on the basis of mineralography and mineral chemistry of pyrites.

\subsubsection{Diagenetic stage}

Py I occurs both as individual microcrystals as well as the porous core of Py II. Py I occurring as the core of Py II provided sites for the precipitation of Py II. Py I and Py II occur as disseminated grains within the carbonaceous laminations in phyllite. Ilmenite in the carbonaceous phyllites reacted with the seawater sulphate, which were further reduced by bacteria to form diagenetic pyrite. This promoted the migration of $\mathrm{Au}, \mathrm{As}$ and other trace elements from the organic matter into the lattice of pyrites during diagenesis (Tribovillard et al. 2006). This diagenetic pyrite in the study area is characterised by low-tomoderate concentrations of $\mathrm{Au}, \mathrm{As}, \mathrm{Mo}, \mathrm{Ag}, \mathrm{Bi}, \mathrm{Pb}$ and $\mathrm{Zn}$, which also occur in the organic rich metasedimentary environments in higher quantities (Algeo and Maynard 2004; Rimmer 2004; Tribovillard et al. 2006). These trace elements were released from Py I into the metamorphic hydrothermal fluid during greenschist to the amphibolitic facies metamorphism of the host rock (Pitcairn et al. 2006, 2010; Large et al. 2007, 2009, 2011).

Pyrrhotite (Po I), although intimately associated with carbonaceous matter, is not considered to be of sedimentary origin because authigenic pyrrhotite is unstable in reducing environments and eventually gets transformed into pyrite ( $c f$. Berner 1984; Horng and Roberts 2006; Rickard and Luther 2007; Asael et al. 2013). A few occurrences of pyrrhotite along with other metastable and authigenic sulphides such as greigite have been reported only from the sedimentary formations of the Cretaceous to the Holocene epoch (Kao et al. 2004; Larrasoan̈a et al. 2007).
Pyrrhotite in sedimentary environments cannot get through a long period of geological time (Kao et al. 2004). Pyrite generally gets converted to pyrrhotite in the presence of excess of organic matter during increasing metamorphism (Thomas et al. 2011; Asael et al. 2013). The Po I observed along the carbonaceous matter in the phyllites formed due to the breakdown of diagenetic pyrites during prograde metamorphism which is evident by the presence of microcrystals and rounded to subrounded porous Po I similar to that of Py I (figure $4 \mathrm{~b}-\mathrm{d}$ ). The conversion of diagenetic pyrite to pyrrhotite during prograde metamorphism of carbonaceous host rocks generated sulphurous hydrothermal fluids containing various trace elements, which later promoted the formation of hydrothermal pyrites (Tomkins 2010). Gold occurs as lattice bound gold within the diagenetic pyrite $\mathrm{Py} I$ (figure 11c). In the X-ray elemental maps, some portions (red and green patches) towards the core of Py I are enriched in gold. Gold inclusions always appear brighter than their host pyrite in the back-scattered electron (BSE) images. Hence, the red patches are not tiny inclusions of gold as there are no bright spots in the BSE image. High concentrations of invisible gold are observed towards both the core and rim, which could be due to metal diffusion during metamorphism or dissolution of these elements during interaction with the hydrothermal fluid (figure 13). It is evident from the above studies that the disseminated diagenetic pyrite within the carbonaceous layers, initially had elevated concentrations of $\mathrm{Au}$ and related trace elements.

\subsubsection{Hydrothermal stage}

The continuous supply of hydrothermal fluids resulted in overpressuring in the interior of the carbonaceous rocks thereby causing brittle failure and generation of numerous fractures ( $c f$. Wu et al. 2018). During this process, hydrothermal fluids precipitated within the fractures as sulphidehosted quartz/quartz-carbonate veins, which are considered preferred sites for mineralisation during deformation ( $c f$. Goldfarb et al. 1988, 2005; Callan 1991). Py III-bearing quartz \pm carbonate veins suffered deformation due to brittle-ductile shearing as evident from recrystallised quartz, quartz strain fringes, fracturing and grain size reduction of Py III (figures 3c, 5b-e, 6a, 7b and c). Py I and Py II were also affected by deformation. The folded and boudinaged veinlets consisting of Py III 


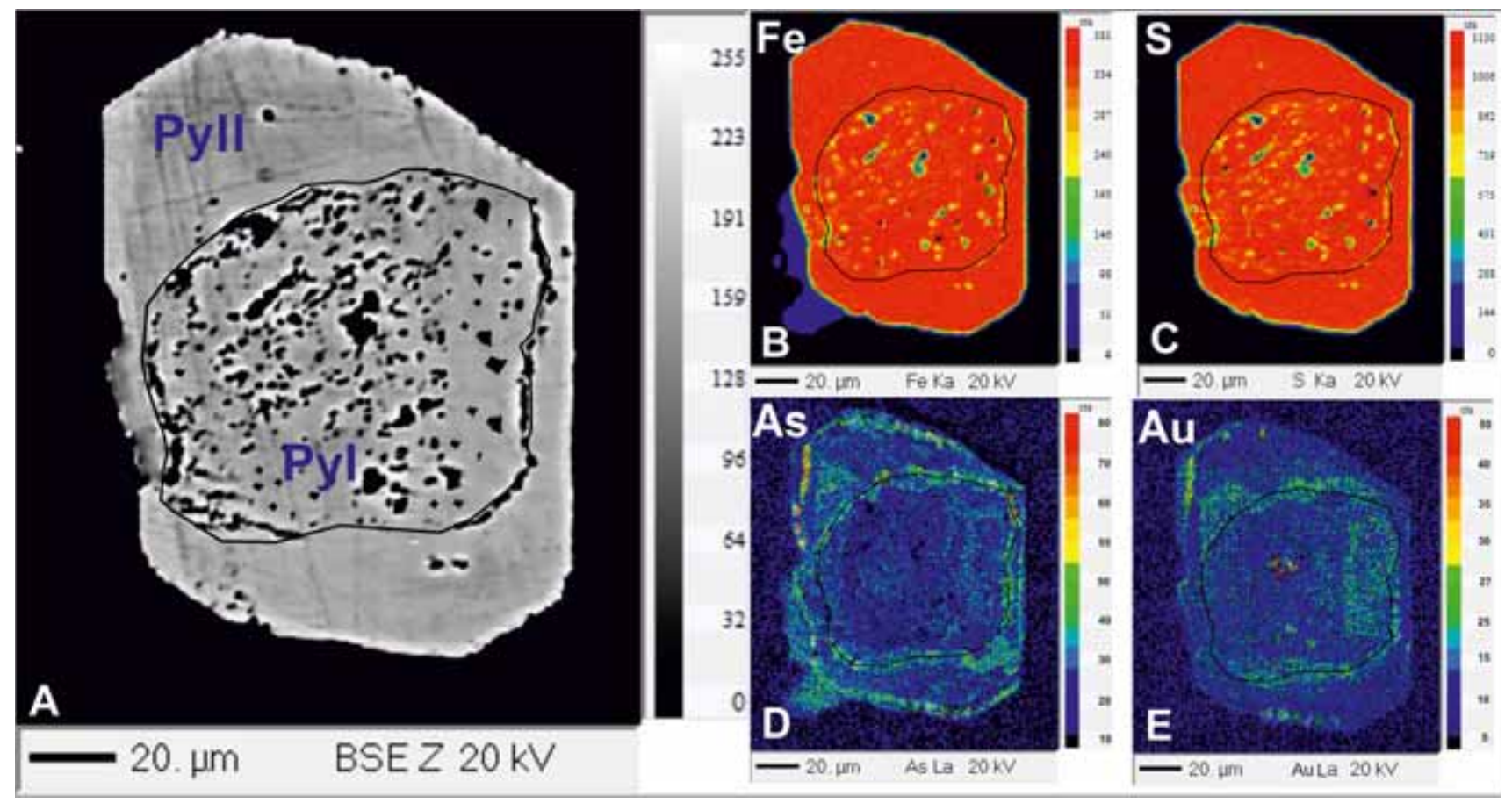

Figure 13. (a) BSE image of Py I and Py II and (b)-(e) X-ray element maps showing the distribution of Fe, S, As and Au in Py I and Py II.

(figure 7c) indicate that these veins were emplaced at an early stage of deformation. These deformed veins created low stress sites for the localisation of fluids generated during subsequent deformation into the same structural setup resulting in a complex network of veins ( $c f$. Siddorn 2010). These fluids were responsible for the formation of Py IV.

This mineralised vein geometry was controlled by the ductile to brittle-ductile shear zone cutting across the carbonaceous pelitic metasedimentary rocks. The hydrothermal fluid responsible for the formation of Py III also interacted with the host rocks and precipitated Py II around Py I. Py II and Py III are of the same generation and nearly similar composition. The As-rich zones surrounding Py I within Py II show gold enrichment (figure 13). This is possible either by metal diffusion or dissolution of Py I during the hydrothermal fluid flow (Large et al. 2007, 2009). The hydrothermal pyrite II has a thin As-rich rim associated with high-Au content. This indicates that the second generation gold event occurred during the initial phase of deformation and hydrothermal activity (figure 13).

There is a systematic variation in other traceelement concentrations between the peripheral region and core parts of pyrites and it indicates that the fluid condition during pyrite formation or the physico-chemical changes in the parent fluid was not constant. Gold and arsenic concentrations are homogeneous throughout the surface of Py III (figure 14). The cores of Py III show higher concentrations of As and contents of $\mathrm{Au}$ are also high at some portions of these arsenic-rich zones with respect to the rim. The arsenic and gold concentrations in Py III are positively correlated, which indicate that $\mathrm{As}$ has facilitated the intake of $\mathrm{Au}$ in the structure of Py III (figure 11c). Mineral assemblages of quartz, carbonates, muscovite, biotite (Ugarkar 1998; figure 7d) and the lack of potassium feldspar in the carbonaceous phyllites indicate near neutral to slightly acidic hydrothermal fluids $\left(250-300^{\circ} \mathrm{C}\right.$ temperature and $1 \mathrm{kbar}$ pressure) and that $\mathrm{Au}$ is preferentially transported as $\mathrm{Au}(\mathrm{HS})_{2}^{-}$or $\mathrm{Au}(\mathrm{HS})_{(\mathrm{aq})}$ (Johnson et al. 1991; Mikucki 1998; Stefánsson and Seward 2004). Arsenian pyrites are metastable, and rapidly precipitate which typically indicates their formation at relatively low temperature conditions (Abraitis et al. 2004). The hydrothermal solutions that precipitated Py II and Py III were undersaturated with $\mathrm{Au}$ as observed by the gold and arsenic concentrations falling below the gold solubility limit in the $\mathrm{Au}$ vs. As plot (figure 11c). The positive correlation between $\mathrm{Au}$ and As implies that gold incorporation in the arsenian pyrite is facilitated by the excess quantity of arsenic. There could be three possible key factors responsible for mineralisation in carbonaceous phyllites along SPSZ, viz., 


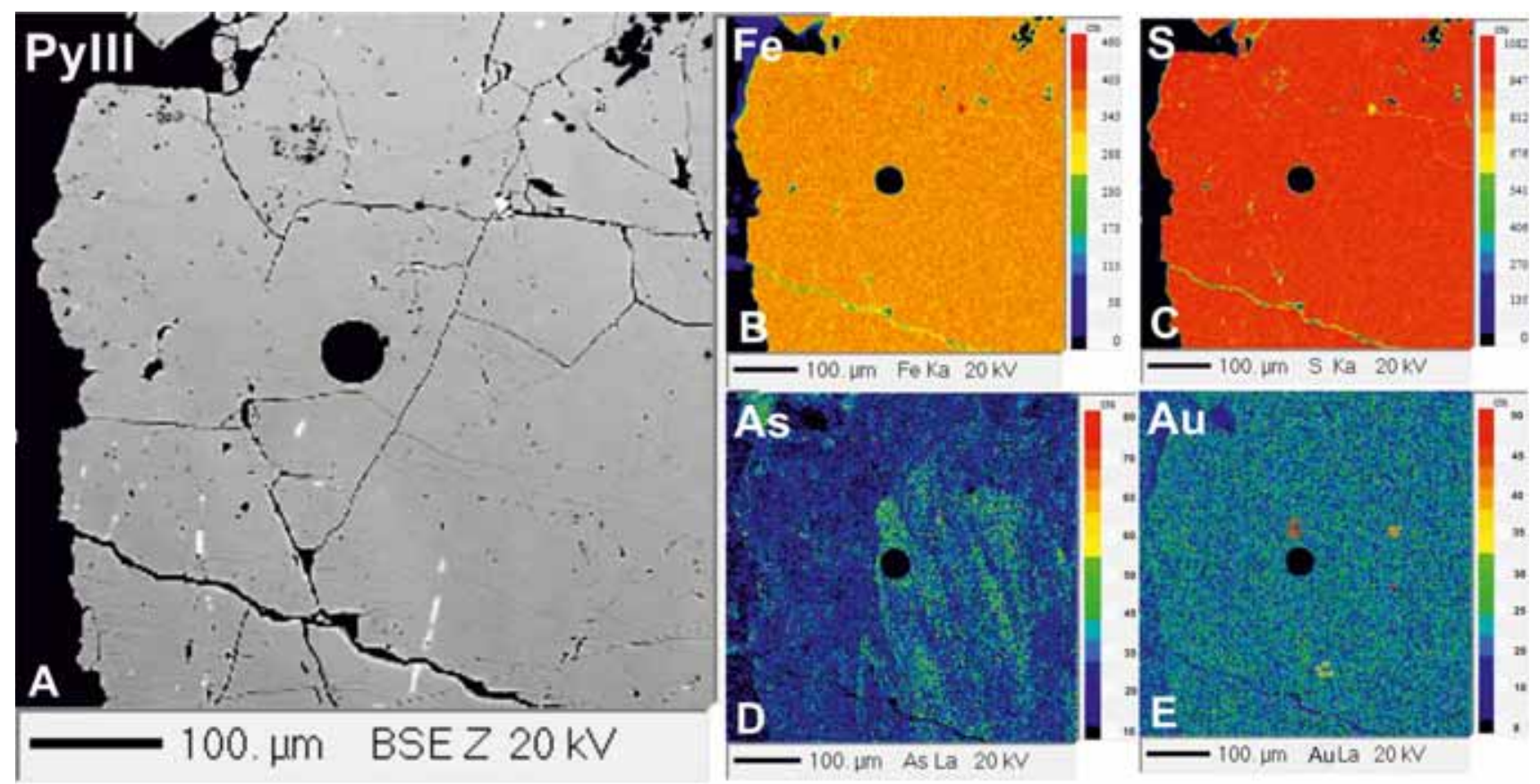

Figure 14. (a) BSE image of Py III showing microfractures and LA-ICP-MS spot and (b)-(e) X-ray element maps showing the distribution of Fe, S, As and $\mathrm{Au}$ in Py III.

(i) reducing conditions provided by abundant organic matter in the host rocks; (ii) interaction of ore-bearing hydrothermal fluids with host rocks and (iii) the presence of arsenian pyrites. Arsenic is transported as a $\mathrm{HAsS}_{2(\mathrm{aq})}$ complex in hydrothermal fluids undersaturated with $\mathrm{Au}$, and $\mathrm{Au}$ can be removed from these fluids by adsorption during the growth of arsenian pyrite as follows (Reich et al. 2005):

$$
\begin{array}{r}
\mathrm{Fe}^{2+}+2 \mathrm{HAsS}_{2(\mathrm{aq})}+2 \mathrm{Au}(\mathrm{HS})_{(\mathrm{aq})}^{0}+2 \mathrm{H}_{2(\mathrm{~g})} \\
=\mathrm{Fe}(\mathrm{S}, \mathrm{As})_{2} \cdot \mathrm{Au}_{2} \mathrm{~S}^{0}+3 \mathrm{H}_{2} \mathrm{~S}_{(\mathrm{aq})}+2 \mathrm{H}^{+} .
\end{array}
$$

Sulphidation of iron-bearing minerals (ilmenite, Fe carbonates and biotite) in host rocks inhibits the activity of the bisulphide ion $\left(\mathrm{H}_{2} \mathrm{~S}\right)$ in the hydrothermal fluid and in turn depresses the solubility of gold, thereby causing gold precipitation in the pyrite lattice. The hydrothermal pyrites, Py II and Py III show roughly similar geochemical signatures, as a result of the influx of the same hydrothermal fluid during deformation and metamorphism ( $c f$. Sahoo and Venkatesh 2015). The coarse grains of Py III as compared to Py II suggest prolonged precipitation from the hydrothermal fluid. These pyrites have relatively higher concentrations of $\mathrm{Cu}, \mathrm{Ni}, \mathrm{Zn}, \mathrm{Mo}, \mathrm{Au}, \mathrm{Pb}, \mathrm{Bi}$ and As in comparison with the diagenetic Py I. Devolatilisation of significant quantity of $\mathrm{Au}, \mathrm{As}$ and $\mathrm{S}$, from the lattice of Py I into the metamorphic hydrothermal fluid from which Py II and Py III precipitated, is responsible for the trace elemental concentrations in these pyrites. The subsequent deformational events after the formation of Py III facilitated another phase of fluid circulation and remobilisation of lattice-bound trace elements within the structure of Py III to form inclusions of other sulphides such as galena along micro fractures during greenschist to lower amphibolite facies metamorphism ( $c f$. Belousov et al. 2016; figure 5d).

Py IV is devoid of any deformational features, which indicate its formation later than the deformational events. It occurs in the latest quartz \pm carbonate veins cutting across the previously formed mineralised veins. The dissimilar geochemical characteristics of Py IV from that of earlier generations of pyrites (Py II and Py III) and also its occurrence in quartz \pm carbonate veins not consisting of Py III indicate that Py IV formed from a different ore fluid. Generally, the presence of quartz-carbonate veins in metapelites creates huge contrasts in competence between the veins, which are strong and the weak host rocks (Siddorn 2010). This promotes further deformation, hydrothermal activity and mineralisation. As a result of which pre-existing veins boudinage/fracture thereby creating favourable low-stress areas that promote the localisation of subsequent veins into the same structural site (Siddorn 2010). Similarly, the preexisting Py III-bearing veins were boudinaged and 


\begin{tabular}{|c|c|c|c|c|}
\hline MINERALS & $\begin{array}{l}\text { SEDIMENTATI } \\
\text { ON- } \\
\text { DIAGENESIS }\end{array}$ & \multicolumn{2}{|c|}{$\begin{array}{l}\text { DEFORMATION- } \\
\text { METAMORPHISM }\end{array}$} & $\begin{array}{l}\text { POST } \\
\text { DEFOR- } \\
\text { MATION }\end{array}$ \\
\hline Ilmenite & 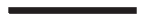 & & & \\
\hline \multirow{2}{*}{ Pyrite } & \multirow[t]{2}{*}{ Py I } & & Py II & \multirow[b]{2}{*}{ Py IV } \\
\hline & & & Py III & \\
\hline \multicolumn{5}{|l|}{$\begin{array}{l}\text { Invisible gold in } \\
\text { pyrite }\end{array}$} \\
\hline Pyrrholite & & Pol & Po II & Po III \\
\hline \multicolumn{5}{|l|}{$\begin{array}{l}\text { Sulfide quartz } \\
\text { carbonate veins }\end{array}$} \\
\hline \multicolumn{5}{|l|}{ Arsenopyrite } \\
\hline Sphalerite & & & Sp I & Sp II \\
\hline \multicolumn{5}{|l|}{ Galena } \\
\hline Chalcopyrite & & & Ccp 1 & Ccp II \\
\hline
\end{tabular}

Figure 15. Possible paragenetic sequence of various stages of mineralisation in carbonaceous phyllite along SPSZ interpreted from the textural relationships of different generations of pyrites with other sulphide minerals. The bold lines represent more abundance whereas thin lines indicate lesser concentration.

fractured at certain places during deformation, which promoted the localisation of subsequent hydrothermal fluids responsible for the formation of Py IV-bearing quartz \pm carbonate veins. It is at these places, Py III and Py IV appear to co-occur in the Py III-bearing veins. The concentration of certain metals $(\mathrm{Cu}, \mathrm{Zn}, \mathrm{As}, \mathrm{Mo}, \mathrm{Ag}, \mathrm{Pb}$ and $\mathrm{Bi})$ in this post-deformational pyrite (Py IV) is lower than the other generations of pyrites in the carbonaceous phyllites. Both Py III and IV are devoid of any signatures of early generation pyrites (Py I) in the core, which indicates their direct precipitation from the hydrothermal fluid.

Based on ore texture, structure, mineral assemblages and pyrite geochemistry, the possible paragenetic sequence of mineralisation in carbonaceous phyllite of SPSZ is established (figure 15). The metal contents of the hydrothermal pyrites differ prominently as compared to that of the diagenetic pyrites. It is possibly due to certain factors such as the availability and solubility of elements in the ore-forming fluids (Large et al. 2009).

\section{Conclusions}

Pyrite-hosted refractory gold mineralisation is associated with the carbonaceous metasedimentary units of the SPSZ. The study of textural and chemical evolution of auriferous pyrite indicates four types of pyrites. Py I is diagenetic in origin whereas Py II and Py III formed during the early hydrothermal stage. Py IV formed during the latter phase of hydrothermal activities after the deformational episodes. Gold mineralisation within the SPSZ occurs as invisible gold within all generations of pyrites. The trace element distribution is mostly lattice bound due to the substitution of $\mathrm{Fe}$ and $\mathrm{S}$ in all generations of pyrites. The trace elements in diagenetic pyrite were locked up in their lattice during diagenesis.

Mineral chemistry of various generations of pyrites confirms the derivation of hydrothermal fluids from the carbonaceous host rocks during prograde metamorphism at depth with a notable quantity of trace elements. The presence of $\mathrm{Au}$ in diagenetic pyrite indicates that the gold was introduced at an early stage, which subsequently acted as a source of gold mineralisation, deposited later during the hydrothermal activity in the study area. During the prograde metamorphism, various trace elements including $\mathrm{As}$ and $\mathrm{Au}$ were released from the diagenetic pyrite (Py I) to the metamorphic ore-forming fluid. This promoted the formation of gold-bearing hydrothermal pyrite (Py II and Py III). The release of trace elements into the orebearing fluids was facilitated by the conversion of diagenetic pyrite to pyrrhotite during prograde metamorphism.

The organic matter facilitated the precipitation of auriferous pyrites. Py III contains the highest concentrations of invisible gold, which occurs as a solid solution. A considerable difference in gold concentration was observed between diagenetic pyrite (Py I) and hydrothermal pyrite. Py IV precipitated from late phases of hydrothermal fluid and it is evident from its different mineral chemistry from that of Py II and Py III. The textural and chemical evolution of different generations of pyrites suggest a multistage process of ore genesis and further investigation will supplement the exploration activities for gold in the SPSZ.

\section{Acknowledgements}

The authors would like to thank the Director, Indian Institute of Technology (Indian School of Mines), Dhanbad for providing necessary facilities; IIT (ISM) Central Research Facility, for Electron Probe Micro Analysis; Dr Dewashish Upadhyay, IIT Kharagpur, for his permission and necessary help for LA-ICP-MS analyses; and Dr Shiladitya Sengupta, 
Director, LA-ICP-MS Laboratory, Geological Survey of India, Faridabad, for his permission and necessary help with the LA-ICP-MS analyses. They also thank SAIF, IIT Bombay for allowing to avail the FTIR facility. SS is thankful to the Department of Science and Technology (DST), New Delhi for some of the facilities under Project No. NRDMS (01/07/014). Thanks are also due to Prof Chalapathi Rao and Prof Pulak Sengupta for their editorial handling. Authors are grateful for the constructive comments of the anonymous reviewer, which has helped improve the manuscript. We thankfully acknowledge Atomic Minerals Directorate for Exploration and Research, Jamshedpur for providing the samples and helping SM with the field work. SM extends her gratitude to the Indian Institute of Technology (Indian School of Mines), Dhanbad for the financial support required for her research fellowship.

\section{References}

Abraitis P K, Pattrick R A D and Vaughan D J 2004 Variations in the compositional, textural and electrical properties of natural pyrite: A review; Int. J. Miner. Process. 74 41-59.

Acharyya A, Ray S, Chaudhuri B K, Basu S K, Bhaduri S K and Sanyal A K 2006 Proterozoic rock suites along South Purulia Shear Zone, eastern India: Evidence for rift-related setting; J. Geol. Soc. India 68 1069-1086.

Algeo T J and Maynard J B 2004 Trace-element behavior and redox facies in core shales of Upper Pennsylvanian Kansastype cyclothems; Chem. Geol. 206 289-318.

Anjos C W D D, Meunier A, Guimaraes E M and Albani A E 2010 Saponite-rich black shales and nontronite beds of the Permian Irati Formation: Sediment sources and thermal metamorphism (Parana Basin, Brazil); Clays Clay Miner. $\mathbf{5 8} 606-626$.

Arehart G B, Chryssoulis S L and Kesler S E 1993 Gold and arsenic in iron sulfides from sediment-hosted disseminated gold deposits: Implications for depositional processes; Econ. Geol. 88 171-185.

Asael D, Tissot F L H, Reinhard C T, Rouxel O, Dauphas N, Lyons T W, Ponzevera E, Liorzou C and Cheron S 2013 Coupled molybdenum, iron and uranium stable isotopes as oceanic paleoredox proxies during the Paleoproterozoic Shunga Event; Chem. Geol. 362 193-210.

Belousov I, Large R R, Meffre S, Danyushevsky L V, Steadman J and Beardsmore T 2016 Pyrite compositions from VHMS and orogenic $\mathrm{Au}$ deposits in the Yilgarn Craton, Western Australia: Implications for gold and copper exploration; Ore Geol. Rev. 79 474-499.

Berner R A 1984 Sedimentary pyrite formation: An update; Geochim. Cosmochim. Acta 48 605-615.

Bhattacharya S 1989 Ductile shear zone in Purulia, West Bengal; Indian J. Geol. 61 172-178.
Bonnemaison M and Marcoux E 1990 Auriferous mineralization in some shear-zones: A three-stage model of metallogenesis; Miner. Deposita 25 96-104.

Bralia A, Sabatini G and Troja F 1979 A revaluation of the $\mathrm{Co} / \mathrm{Ni}$ ratio in pyrite as geochemical tool in ore genesis problems; Miner. Deposita 14 353-374.

Buerger M J 1936 The symmetry and crystal structure of minerals of the arsenopyrite group; Z. Kristallogr. 95 83-113.

Cabral A R, Beaudoin G and Munnik F 2011 Lead in diagenetic pyrite: Evidence for Pb-tolerant bacteria in a red-bed $\mathrm{Cu}$ deposit, Quebec Appalachians, Canada; Mineral. Mag. 75 295-302.

Cabral A R, Creaser R A, Nagler T, Lehmann B, Voegelin A R, Belyatsky B, Pasava J, Seabra Gomes A A Jr, Galbiatti H, Bottcher M E and Escher P 2013 Trace-element and multiisotope geochemistry of Late-Archean black shales in the Carajás iron-ore district, Brazil; Chem. Geol. 362 91-104.

Callan N J 1991 Syn-deformational shear zone-hosted Auquartz vein mineralization in TTG host rocks, Renabi mine area, North Ontario: Structural analysis, microstructural characteristics and vein paragenesis; Ontario Geol. Survey.

Calvert S E, Bustin R M and Ingall E D 1996 Influence of water column anoxia and sediment supply on the burial and preservation of organic carbon in marine shales; Geochim. Cosmochim. Acta 60 1577-1593.

Caplan M L and Bustin R M 1998 Palaeoceanographic controls on geochemical characteristics of organic-rich Exshaw mudrocks: Role of enhanced primary production; Org. Geochem. 30 161-188.

Chandan K K, Jha V, Sairaj K, Singh S and Venkatesh A S 2013 Greenfield exploration prospects of orogenic gold mineralization in and around Lawa area, North Singhbhum mobile belt, Eastern India Craton; Int. J. Appl. Nat. Sci. 2 81-90.

Chakrabarty A, Sen A K and Ghosh T K 2009 Amphibole - a key indicator mineral for petrogenesis of the Purulia carbonatite, West Bengal, India; Mineral. Petrol. 95 105-112.

Chatterjee P, De S, Ranaivoson M, Mazumder R and Arima M 2013 A review of the $\sim 1600$ Ma sedimentation, volcanism, and tectono-thermal events in the Singhbhum craton, Eastern India; Geosci. Front. 4 277-287.

Cline J S, Hofstra A H, Muntean J L, Tosdal R M and Hickey K A 2005 Carlin-type gold deposits in Nevada: Critical geological characteristics and viable models; Econ. Geol. 100 451-484.

Cook N J 1996 Mineralogy of the sulfide deposits at Sulitjelma, northern Norway; Ore Geol. Rev. 11 303-338.

Cook N J and Chryssoulis S L 1990 Concentrations of invisible gold in common sulfides; Can. Mineral. 28 1-16.

Cox S F, Wall V J, Etheridge M A and Potter T F 1991 Deformational and metamorphic processes in the formation of mesothermal vein-hosted gold deposits: Examples from the Lachlan Fold Belt in central Victoria, Australia; Ore Geol. Rev. 6 391-423.

Deditius A P, Utsunomiya S, Renock D, Ewing R C, Ramana C V, Becker U and Kesler S E 2008 A proposed new type of arsenian pyrite: Composition, nanostructure and geological significance; Geochim. Cosmochim. Acta 72 2919-2933.

Deditius A P, Utsunomiya S, Ewing R C, Chryssoulis S L, Venter D and Kesler S E 2009 Decoupled geochemical 
behaviour of $\mathrm{As}$ and $\mathrm{Cu}$ in hydrothermal systems; Geology 37 707-710.

Deditius A, Utsunomiya S, Reich M, Kesler S E, Ewing R C, Hough R and Walshe J 2011 Trace metal nanoparticles in pyrite; Ore Geol. Rev. 42 32-46.

Dill H and Kemper E 1990 Crystallographic and chemical variations during pyritization in the upper Barremian and lower Aptian dark claystones from the Lower Saxonian basin (NW Germany); Sedimentology 37 427-443.

Durand B and Nicaise G 1980 Procedures for kerogen isolation; In: Kerogen-Insoluble Organic Matter from Sedimentary Rocks (ed.) Durand B, Paris Editions Technip, pp. $35-53$.

Dwivedi A K, Pandey U K, Murugan C, Bhatt K, Babu P V R and Joshi M 2011 Geochemistry and geochronology of A-type Barabazar granite: Implications on the geodynamics of South Purulia Shear Zone, Singhbhum Craton, Eastern India; J. Geol. Soc. India 77 527-538.

Fleet M E and Mumin A H 1997 Gold-bearing arsenian pyrite and marcasite and arsenopyrite from Carlin Trend gold deposits and laboratory synthesis; Am. Mineral. 82 182-193.

Fleet M E, Chryssoulis S L, Maclean P J, Davidson R and Weisener G G 1993 Arsenian pyrite from gold deposits: Au and As distribution investigated by SIMS and EMP, and color staining and surface oxidation by XPS and LIMS; Can. Mineral. 31 1-17.

Friedl J, Wagner F E and Wang N 1995 On the chemical state of combined gold in sulfidic ores: Conclusions from Mössbauer source experiments; Neues Jb. Mineral. Abh. 169 279-290.

Giri R K, Pandit D and Rao N V C 2018 Cobaltoan pyrite in a Lamprophyre from the Sidhi Gneissic Complex, Mahakoshal belt, Central India; J. Geol. Soc. India 91 5-8.

Goldfarb R J, Leach D L, Pickthorn W J and Paterson C J 1988 Origin of lode-gold deposits of the Juneau gold belt, south eastern Alaska; Geology 16 440-443.

Goldfarb R J, Ayuso R, Miller M L, Ebert S W, Marsh E E, Petsel S A, Miller L D, Bradley D, Johnson C and McClelland W 2004 The Late Cretaceous Donlin Creek Gold deposit, Southwestern Alaska: Controls on epizonal ore formation; Econ. Geol. 99 643-671.

Goldfarb R, Baker T, Dube B, Groves D I, Hart C J R and Gosselin P 2005 Distribution, character and genesis of gold deposits in metamorphic terranes; Econ. Geol. 100 407-450.

Gregory D D, Large R R, Halpin J A, Baturina E L, Lyons T W, Wu S, Danyushevsky L, Sack P J, Chappaz A, Maslennikov V V and Bull S W 2015 Trace element content of sedimentary pyrite in black shales; Econ. Geol. 110 1389-1410.

Groves D I and Santosh M 2015 Province-scale commonalities of some world-class gold deposits: Implications for mineral exploration; Geosci. Front. 6(3) 389-399.

Groves D I, Goldfarb R J, Robert F and Hart C J R 2003 Gold deposits in metamorphic belts: Overview of current understanding, outstanding problems, future research, and exploration significance; Econ. Geol. 98 1-29.

Gupta A and Basu A 2000 North Singhbhum Proterozoic mobile belt Eastern India - a review; Geol. Surv. India, Spec. Publ. 55 195-226.

Guy B, Beukes N and Gutzmer J 2010 Paleoenvironmental controls on the texture and chemical composition of pyrite from nonconglomeratic sedimentary rocks of the Mesoarchean Witwatersrand Supergroup, South Africa; S. Afr. J. Geol. 113 195-228.

Hart C Jr 2005 Classifying, distinguishing and exploring for intrusion-related gold systems; Gangue MDD Newsl. $\mathbf{8 7}$ $3-9$.

Hawley J E and Nichol I 1961 Trace elements in pyrite, pyrrhotite and chalcopyrite of different ores; Econ. Geol. 56 467-487.

Hazarika P, Mishra B, Chinnasamy S S and Bernhardt H J 2013 Multi-stage growth and invisible gold distribution in pyrite from the Kundarkocha sediment-hosted gold deposit, eastern India; Ore Geol. Rev. 55 134-145.

Hodgson C J 1989 The structure of shear related, vein type gold deposits: A review; Ore Geol. Rev. 4 231-273.

Horng C and Roberts A P 2006 Authigenic or detrital origin of pyrrhotite in sediments?: Resolving a paleomagnetic conundrum; Earth Planet. Sci. Lett. 241 750-762.

Huston D L, Sie S H, Suter G F, Cooke D R and Both R A 1995 Trace elements in sulfide minerals from eastern Australian volcanic hosted massive sulfide deposits; Part I, proton microprobe analyses of pyrite, chalcopyrite, and sphalerite, and part II, selenium levels in pyrite; comparison with delta $34 \mathrm{~S}$ values and implications for the source of sulfur in volcanogenic hydrothermal systems; Econ. Geol. $901167-1196$.

Huston D L 2000 Gold in volcanic-hosted massive sulfide deposits: Distribution, genesis and exploration; Econ. Geol. 13 401-426.

Hyland M M and Bancroft G M 1989 An XPS study of gold deposition at low temperatures on sulphide minerals: Reducing agents; Geochim. Cosmochim. Acta 53 367372.

Jean G E and Bancroft G M 1985 An XPS and SEM study of gold deposition at low temperatures on sulphide mineral surfaces: Concentration of gold by adsorption/reduction; Geochim. Cosmochim. Acta 49 979-987.

Jensen E P and Barton M D 2000 Gold deposits related to alkaline magmatism; Econ. Geol. 13 279-314.

Jha V, Singh S and Venkatesh A S 2015 Invisible gold occurrence within the quartz reef pyrite of Babaikundi area, North Singhbhum fold thrust belt, Eastern Indian Shield. Evidences from Petrographic, SEM and EPMA studies; Ore Geol. Rev. 65 426-432.

Johnson J W, Oelkers E H and Helgeso H C 1991 SUPCRT92, a software package for calculating the standard molal thermodynamic properties of minerals, gases, aqueous species, and reaction from 1 to 5000 bars and 0 to $1000^{\circ} \mathrm{C}$; Comput. Geosci. 18 899-947.

Kao S J, Horng C S, Roberts A P and Liu K K 2004 Carbon-sulfur-iron relationships in sedimentary rocks from southwestern Taiwan: Influence of geochemical environment on greigite and pyrrhotite formation; Chem. Geol. 203 153-168.

Katti V J, Sen J and Bhatt A K 2010 Uranium potentiality of South Purulia Shear Zone, Eastern India Shield; Presented in technical committee meeting on low grade uranium deposits, IAEA.

Khodary S A E, Enany G M E, Okr M E and Ibrahim M 2014 Preparation and characterization of microwave reduced graphite oxide for high-performance supercapacitors; Electrochim. Acta 150 269-278. 
Large R R, Maslennikov V V, Robert F, Danyushevsky L V and Chang Z S 2007 Multistage sedimentary and metamorphic origin of pyrite and gold in the giant Sukhoi Log deposit, Lena gold province, Russia; Econ. Geol. 102 1233-1267.

Large R R, Danyushevsky L, Hollit C, Maslennikov V, Meffre S, Gilbert S, Bull S, Scott R, Emsbo P, Thomas H, Singh B and Foster J 2009 Gold and trace element zonation in pyrite using a laser imaging technique: Implications for the timing of gold in orogenic and Carlin-style sediment-hosted deposits; Econ. Geol. 104 635-668.

Large R R, Bull W B and Maslennikov V V 2011 A carbonaceous sedimentary source-rock model for Carlintype and orogenic gold deposits; Econ. Geol. 106 331-358.

Large R R, Halpin J A, Danyushevsky L V, Maslennikov V V, Bull S W, Long J A, Gregory D D, Lounejeva E, Lyons T W, Sack P J, McGoldrick P J and Calver C R 2014 Trace element content of sedimentary pyrite as a new proxy deeptime ocean-atmosphere evolution; Earth Planet. Sci. Lett. 389 209-220.

Larrasoan̈a J C, Roberts A P, Musgrave R J, Gràcia E, Pin̈ero E, Vega M and Martínez-Ruiz F 2007 Diagenetic formation of greigite and pyrrhotite in gas hydrate marine sedimentary systems; Earth Planet. Sci. Lett. 261 $350-366$.

Li N, Deng J, Yang L-Q, Goldfarb R J, Zhang C, Marsh E, Lei S-B, Koenig A and Lowers H 2014 Paragenesis and geochemistry of ore minerals in the epizonal gold deposits of the Yangshan gold belt, West Qinling, China; Miner. Deposita 49 427-449.

Loftus-Hills G and Solomon M 1967 Cobalt, nickel and selenium in sulphides as indicators of ore genesis; Miner. Deposita 2 228-242.

Maddox L M, Bancroft G M, Scaini M J and Lorimer J W 1998 Invisible gold; comparison of $\mathrm{Au}$ deposition on pyrite and arsenopyrite; Am. Mineral. 83 1240-1245.

Mikucki E J 1998 Hydrothermal transport and depositional processes in Archean lode-gold systems: A review; Ore Geol. Rev. 13 307-321.

Mironov A G, Zhodik S M and Maksimova E A 1981 An experimental investigation of the sorption of gold by pyrites with different thermoelectric properties; Geochem. Int. 18 153-160.

Majumdar S, Singh S and Sahoo P R 2017 Petrographic characterisation of host rocks and ore mineralisation from Palaeo to Mesoproterozoic South Purulia Shear Zone, Eastern Indian Craton; J. Geosci. Res. 1 43-50.

Mishra S, Deomurari M P, Wiedenbeck M, Goswami J N, Ray $\mathrm{S}$ and Saha A K $1999{ }^{207} \mathrm{~Pb} /{ }^{206} \mathrm{~Pb}$ zircon ages and the evolution of the Singhbhum Craton, eastern India: An ion microprobe study; Precamb. Res. 93 139-151.

Morad S and Aldahan A A 1986 Alteration of detrital Fe-Ti oxides in sedimentary rocks; Geol. Soc. Am. Bull. 97 $567-578$.

Pal D C, Barton M D and Sarangi A K 2009 Deciphering a multistage history affecting $\mathrm{U}-\mathrm{Cu}(-\mathrm{Fe})$ mineralization in the Singhbhum shear zone, eastern India, using pyrite textures and compositions in the Turamdih $\mathrm{U}-\mathrm{Cu}(-\mathrm{Fe})$ deposit; Miner. Deposita 44 61-80.

Palenik C S, Utsunomiya S, Reich M, Kesler S E, Wang L and Ewing R C 2004 'Invisible' gold revealed: Direct imaging of gold nanoparticles in a Carlin-type deposit; Am. Mineral. 89 1359-1366.

Pasava J, Frimmel H, Vymazalová A, Dobes P, Jukov A V and Koneev R I 2013 A two-stage evolution model for the Amantaytau orogenic-type gold deposit in Uzbekistan; Miner. Deposita 48 825-840.

Pitcairn I K, Roberts S, Teagle D A H and Craw D 2005 Detecting hydrothermal graphite deposition during metamorphism and gold mineralization; J. Geol. Soc. London $162429-432$.

Pitcairn I K, Teagle D A H, Craw D, Olivo G K, Kerrich R and Brewer T S 2006 Sources of metals and fluids in orogenic gold deposits; Insights from the Otago and Alpine schists, New Zealand; Econ. Geol. 101 1525-1546.

Pitcairn I K, Olivo G R, Teagle G A H and Craw D 2010 Sulfide evolution during prograde metamorphism of the Otago and Alpine Schists, New Zealand; Can. Mineral. 48 1267-1295.

Reich M, Kesler S E, Wang L M, Ewing R C and Becker U 2005 Solubility of gold in arsenian pyrite; Geochim. Cosmochim. Acta 69 2781-2796.

Reich M, Deditius A, Chryssoulis S, Li J-W, Ma C-Q, Parada A P, Barra F and Mittermayr F 2013 Pyrite as a record of hydrothermal fluid evolution in a porphyry copper system: A SIMS/EPMA trace element study; Geochim. Cosmochim. Acta 102 42-62.

Rickard D and Luther G W 2007 Chemistry of iron sulfides; Chem. Rev. 107 514-562.

Rimmer S M 2004 Geochemical paleoredox indicators in Devonian-Mississippian black shales, Central Appalachian basin, USA; Chem. Geol. 206 372-391.

Saha A K 1994 Crustal evolution of Singhbhum-North Orissa, Eastern India; Geol. Soc. India Memoir 27341.

Saha I and Venkatesh A S 2002 Invisible gold within sulfides from Archean Hutti-Maski schist belt, Southern India; J. Asian Earth Sci. 20 449-457.

Sahoo P R and Venkatesh A S 2014 'Indicator' carbonaceous phyllite/graphitic schist in the Archean Kundarkocha gold deposit, Singhbhum orogenic belt, eastern India: Implications for gold mineralization vis-a-vis organic matter; J. Earth Syst. Sci. 7 1693-1703.

Sahoo P R and Venkatesh A S 2015 Constraints of mineralogical characterization of gold ore: Implication for genesis, controls and evolution of gold from Kundarkocha gold deposit, eastern India; J. Asian Earth Sci. 97 136-149.

Sarkar S C, Gupta A and Basu A 1992 North Singhbhum Proterozoic Mobile belt, Eastern India: Its character, evolution and metallogeny; In: Metallogeny related to tectonics of Proterozoic Mobile belt (ed.) Sarkar S C, Oxford-IBH Publisher, New Delhi, pp. 271-305.

Sarkar G and Ghosh Roy A K 1999 Geochemistry and isotopic characteristics of acid magmatism within Singhbhum craton; Geol. Surv. India 130 12-13.

Seedorff E, Dilles J H, Proffett J M, Einaudi M T, Zurcher L, Stavast W J A, Johnson D A and Barton M D 2005 Porphyry deposits: Characteristics and origin of hypogene features; Econ. Geol. 100 251-298.

Sengupta S, Sarkar G, Ghosh Roy A K, Bhaduri S K, Gupta S $\mathrm{N}$ and Mandal A 2000 Geochemistry and Rb-Sr geochronology of acid tuffs from the northern fringe of the Singhbhum 
craton and their significance in the Precambrian evolution; Indian Miner. 54 43-56.

Shen P, Pan H and Zhu H 2016 Two fluid sources and genetic implications for the Hatu gold deposit, Xinjiang, China; Ore Geol. Rev. 73 298-312.

Siddorn J M 2010 The role of pre-existing veining in the localization of auriferous vein systems: Examples from the Canadian Shield; Prospectors \& Developers Association of Canada.

Simon G, Huang H, Penner-Hahn J E, Kesler S E and Kao L 1999 Oxidation state of gold and arsenic in gold-bearing arsenian pyrite; Am. Mineral. 84 1071-1079.

Simmons S F, White N C and John D A 2005 Geological characteristics of epithermal precious and base metal deposits; Econ. Geol. 100 485-522.

Stefánsson A and Seward T M 2004 Gold (I) complexing in aqueous sulphide solutions to $500^{\circ} \mathrm{C}$ at 500 bar; Geochim. Cosmochim. Acta 68 4121-4143.

Sylvester P J 2008 Matrix effects in laser ablation-ICP-MS; Mineral. Assoc. Can. Short Course 40 67-78.

Sung Y H, Brugger J, Cioban C L, Ping A, Skinner W and Nugus M 2009 Invisible gold in arsenian pyrite and arsenopyrite from a multistage Achaean gold deposit: Sunrise Dam, Eastern Goldfields Province, Western Australia; Miner. Deposita 44 765-791.

Tadesse S 2004 Genesis of the Shear Zone-related gold vein mineralization of the Lega Dembi gold deposit, Adola gold field, Southern Ethiopia; Gondwana Res. 7 481-488.

Tarnocai C A, Hattori K and Cabri L J 1997 'Invisible' gold in sulfides from the Campbell Mine, Red Lake Greenstone Belt, Ontario: Evidence for mineralization during the peak of metamorphism; Can. Mineral. 35 805-815.

Thomas K, Fleming C and Marchbank A 1998 Gold recovery from refractory carbonaceous ores by pressure oxidation, thiosulfate leaching and resin-in-pulp adsorption, US Patent, US5785736 (C22B3/08).

Thomas H V, Large R R, Bull S W, Maslennikov V, Berry R F, Fraser R, Froud S and Moye R 2011 Pyrite and pyrrhotite textures and composition in sediments, laminated quartz veins, and reefs at bendigo gold mine, Australia: Insights for ore genesis; Econ. Geol. 106 1-31.

Tomkins A G and Mavrogenes J A 2001 Redistribution of gold within arsenopyrite and Loellingite during pro- and retrograde metamorphism: Application to timing of mineralization; Econ. Geol. 96 525-534.

Tomkins A G 2010 Windows of metamorphic sulfur liberation in the crust: Implications for gold deposit genesis; Geochim. Cosmochim. Acta 74 3246-3259.

Tribovillard N, Algeo T J, Lyons T and Riboulleau A 2006 Trace metals as paleoredox and paleoproductivity proxies: An update; Chem. Geol. 232 12-32.

Ugarkar A G 1998 Implications of retrograde metamorphism for gold mineralisation in the Greenstone Belts of Northern Dharwar Craton, Karnataka, India; Gondwana Res. 2 $215-219$
Vapnik Y, Bushmin S, Chattopadhyay A and Dolivovodobrovolsky D 2007 Fluid inclusion and mineralogical study of vein-type apatite ores in shear zones from the Singhbhum metallogenetic province, West Bengal, India; Ore Geol. Rev. 32 412-430.

Velasquez G, Beziat D, Salvi S, Siebenaller L, Borisova A Y, Pokrovski G S and Parseval P D 2014 Formation and deformation of pyrite and implications for gold mineralization in the El Callao District, Venezuela; Econ. Geol. 109 457-486.

Wang K, Zhou Y, Sun L and Ren C 1994 Study on the Gold Occurrence from Several Typical Carlin-Type Gold Deposits in China; Publishing house of University of Science \&Technology of China, Hefei, 114p.

Wan R 2001 Importance of metallurgical research on refractory gold ore processing; Min. Eng. 53(11) 41-46.

Wang L and Zhu Y 2015 Multi-stage pyrite and hydrothermal mineral assemblage of the Hatu gold district (west Junggar, Xinjiang, NW China): Implications for metallogenic evolution; Ore Geol. Rev. 69 243-267.

Wickens J, Pekrul J and Cole A 2003 Grindingth circuit improvements at Barrick Goldstrike's Roaster facility; In: Proceedings of the 35 Annual Meeting of the Canadian Mineral Processors, pp 71-82.

Wood B J and Strens R G J 1979 Diffuse reflectance spectra and optical properties of some sulfides and related minerals; Mineral. Mag. 43 509-518.

Wood B J and Kiseeva E S 2015 Trace element partitioning into sulfide: How lithophile elements become chalcophile and vice versa; Am. Mineral. 100 2371-2379.

Wu X and Delbove F 1989 Hydrothermal synthesis of gold bearing arsenopyrite; Econ. Geol. 84 2029-2032.

Wu Y-F, Li J-W, Evans K, Koening A E, Li Z-K, O'Brien H, Lahaye Y, Rempel K, Hu S Y, Zhang Z-P and Yu J-P 2018 Ore-forming processes of the Daqiao Epizonal Orogenic gold deposit, West Qinling Orogen, China: Constraints from textures, trace elements, and sulfur isotopes of pyrite and marcasite, and Raman spectroscopy of carbonaceous material; Econ. Geol. 113 1093-1132.

Yang H Y, Liu Q, Song X L and Dong J K 2013 Research status of carbonaceous matter in carbonaceous gold ores and bio-oxidation pretreatment; Trans. Nonferrous Met. Soc. China 23 3405-3411.

Yannopoulos J C 1991 The Extractive Metallurgy of Gold; Van Nostrand Reinhol, USA.

YongSheng L, ZhaoChu H, Ming L and Shan G 2013 Applications of LA-ICP-MS in the elemental analyses of geological samples; Chinese Sci. Bull. 58(32) 3863-3878.

Zhao H X, Frimmel H E, Jiang S Y and Dai B Z 2011 LA-ICPMS trace element analysis of pyrite from the Xiaoqinling gold district, China: Implications for ore genesis; Ore Geol. Rev. 43 142-153.

Zoheir B A 2008 Characteristics and genesis of shear zonerelated gold mineralization in Egypt: A case study from the Um El Tuyor mine, south Eastern Desert; Ore Geol. Rev. 34 445-470. 